\title{
ANTIHREZA DE LEGE FERENDA
}

Dr. sc. Ines Matić, univ. spec. crim.*

Izv. prof. dr. sc. Anamari Petranović**
UDK: $347.455 .01(37)$

https://doi.org/10.30925/zpfsr.40.1.10

Ur:. 9. siječnja 2019.

Pr.: 8. ožujka 2019.

Izvorni znanstveni rad

\section{Sažetak}

Hrvatski Zakon o vlasništvu i drugim stvarnim pravima člankom 329., stavkom 1., zabranjuje hipotekarnom vjerovniku posjedovanje $i$ upotrebljavanje nekretnine koja je predmet hipoteke, uključujući i ubiranje plodova ili drugih koristi, propisujući stavkom 2. istoga članka kako je ništetna odredba kojom bi se ugovorilo suprotno. Ovom odredbom hrvatski zakonodavac zabranio je pactum antichreticum, dok antihrezu kao samostalni ugovor hrvatsko zakonodavstvo uopće ne poznaje. Cilj je ovoga rada ispitati potencijalne prednosti reguliranja instituta antihreze i/ili pactum antichreticum u hrvatskom pravu de lege ferenda. $U$ tu svrhu u prvome dijelu rada pruža se funkcionalno sažeta povijesno pravna analiza ovih instituta koja propedeutički služi komparativnoj analizi u suvremenom poredbenom pravu, koja je provedena u drugome dijelu rada. Time se u konačnici dolazi do spoznaja o potencijalnim dobrobitima i prednostima korištenja ovih instituta u praksi.

Ključne riječi: antihreza; pactum antichreticum; rimsko pravo; Zakon o vlasništvu i drugim stvarnim pravima; osiguranje tražbine; namirenje tražbine.

\section{POVIJESNI RAZVOJ}

Korijeni instituta pactum antichreticum ${ }^{1}$ sežu u razdoblje Levitskog zakonika, ${ }^{2}$

* Dr. sc. Ines Matić, univ. spec. crim., poslijedoktorandica, Sveučilište u Rijeci, Pravni fakultet, imatic@pravri.hr.

** Dr. sc. Anamari Petranović, izvanredna profesorica, Sveučilište u Rijeci, Pravni fakultet, anamari.petranovic@pravri.hr.

1 Zbog isprepletenosti instituta pactum antichreticum i antihreze koje doktrina vrlo često poima sinonimima, pod pojmom antihreze u ovom slučaju podrazumijevamo i pactum antichreticum i ugovor o antihrezi.

2 Levitski zakonik (lat. Leviticus), treća je knjiga Starog zavjeta i Petoknjižja, kao i židovske Tore, čiji najveći dio sadržaja datira iz 6. st. pr. Kr., a pruža nam dokaze o postojanju instituta pactum antichreticum u 25. poglavlju koje govori o pomoći siromašnima kroz priču o osobi koja je prodala svu obiteljsku imovinu i došla pod vlast druge osobe, ali zapravo ne govori o dužničkom ropstvu, već o zalogu uz pactum antichreticum koji je prijelazni oblik između dužničkog ropstva i prisilne prodaje dužnikove imovine, a omogućuje se uvođenjem fikcije 
odnosno u vrijeme sumerskih, akadskih i mezopotamijskih ${ }^{3}$ kultura. U podatcima o prakticiranju oblika založnog prava (tidennūtu, mazazzānu) ${ }^{4}$ koje je založnog vjerovnika ovlašćivalo na ubiranje plodova založene stvari, a čija je svrha bila kompenzacija plodova s kamatama, moguće je prepoznati značajke rimskog pactum antichreticum i zaključiti kako se radi o višestoljetno primjenjivanom ekonomskom institutu na većinskom dijelu antičkog Bliskog istoka (iako se termin antihreza pojavljuje prvi putu grčkom pravu, ${ }^{5}$ a pactum antichreticum tek u klasičnom rimskom pravu) ${ }^{6}$

Proučavajući karakteristike ovog/ovih instituta u rimskom pravnom sustavu,

koja osiromašenog Izraelca stavlja u položaj kvazistranca. Više Wells, B., The Quasi-Alien in Leviticus 25. The Foreigner and the Law: Perspectives from the Hebrew Bible and the Ancient Near East, Beihefte zur Zeitschrift für altorientalische und biblische Rechtsgeschichte; Bd. 16. Wiesbaden, Germany, Harrassowitz Verlag, 2011., str. 135-155.

3 Hamurabijev zakonik, najbolje sačuvani zakonik drevne Mezopotamije, regulirao je i antihrezni najam. Ovaj ugovor bio je često korišten za vrtove datulja i imao je ključnu ulogu u poljoprivrednoj ekonomiji drevnog Istoka jer je predstavljao prvu invaziju kapitalizma $\mathrm{u}$ poljoprivredno gospodarstvo, koja je potvrđivala prevlast kamata na kapital u odnosu na plodove zemlje, razdvajajući pravo od morala (i problematike nemoralnosti kamata). Prema Ratto, L., I contratti agrari e di lavoro nel codice di Hammurabi, Rivista Internazionale di Scienze Sociali e Discipline Ausiliarie, vol. 35, 138/1904, str. 219-222.

4 O karakteristikama tidennūtu i mazazzānu pravnih transakcija više u: Eichler, B. L., Indenture at Nuzi, The Personal Tidennūtu Contract and its Mesopotamian Analogues, London, Yale University Press, 1973., Ellickson, R. C., Thorland, C., Ancient Land Law: Mesopotamia, Egypt, Israel, Chicago-Kent Law Review, vol. 71/1995, str. 394-399, Speiser, E. A., New Kirkuk Documents Relating to Security Transactions, Journal of the American Oriental Society, vol. 52, 4/1932, str. 350-367, Purves, P. M., Commentary on Nuzi Real Property in the Light of Recent Studies, Journal of Near Eastern Studies, vol. 4, 2/1945 i Additional Remarks on Nuzi Real Property, Journal of Near Eastern Studies, vol. 6, 3/1947, str. 181-185.

5 Iako korijen riječi antichresis možemo pronaći u egipatskom jeziku, naziv potječe iz grčkog jezika te u prijevodu znači uživanje ili uzajamno korištenje, pritom se reflektirajući na vjerovnika koji plodouživa odnosno koristi nekretninu svog dužnika, dok dužnik istovremeno koristi novac svog vjerovnika. Alegre de Miguel, J. D., La anticresis: funcion e finalidad en el Codigo Civil espanol y en el Codigo Civil de Cataluna, Barcelona, ESADE, Facultat de Derecho, Universitat Ramon Llull, 2013., str. 9. Prema Mihelčić, G., Izvansudsko namirenje stvarnopravno osiguranih tražbina, doktorska disertacija, Pravni fakultet Sveučilišta u Zagrebu, 2011., str. 17: „Grčki pravni izvori govore o antihrezi, iako se o ustroju instituta vrlo malo zna, osim da naziv potječe iz grčkog jezika i da je uveden u vrijeme Demostena.“

6 U neoasirskim tekstovima iz prvog tisućljeća pr. Kr. pronađeno je čak jedanaest ugovora s klauzulom o antihreznom zalogu danom umjesto kamata, a osim u ovih jedanaest ugovora koji izričito sadrže klauzulu o kamatama i u drugim se pronađenim ugovorima mogu uočiti značajke antihreznog zaloga, iako se kamate uopće izrijekom ne spominju. Prema Wellsu moguće je identificirati pet osnovnih karakteristika instituta pactum antichreticum u tom razdoblju: postojanje obveznopravnog odnosa između dviju strana, od kojih je jedna dužnik, a druga vjerovnik, izostanak ugovaranja kamate na glavnicu tražbine, funkcija rada založene osobe ili prihoda založene zemlje kao supstituta kamatama koje bi mogle biti drugačije naplaćene, vjerovnikovo posjedovanje založene stvari sve od trenutka zaključenja ugovora o zalogu te mogućnost ugovaranja minimalnog trajanja antihreznog zaloga, kao i definiranje akcesornosti antihreznog zaloga u odnosu na glavnu obvezu, čime se prestanak antihreznog zaloga uvjetuje prestankom glavne obveze. Prema Wells, B., op. cit., str. 135-155. 
unatoč malom broju postojećíh pravnih izvora ${ }^{7} \mathrm{~s}$ velikom sigurnošću možemo zaključiti da je rimsko pravo poznavalo institut pactum antichreticum i institut antihreze ${ }^{8}$ kao dva različita instituta, kojima su zajednički element plodovi, odnosno funkcija namirenja, dok se u ostalim karakteristikama bitno razlikuju.

Pactum antichreticum je uglavak uz ugovor o zalogu ili bilo koji drugi ugovor kojim se ovlašćuje na posjedovanje stvari koja je predmet ugovora i ubiranje njezinih plodova kako bi se kompenzirale kamate. U rimskom pravu pojavljuje se u razdoblju klasike kao pactum adiectum uz contractus pigneraticius. Takav uglavak uz ugovor o zalogu ovlašćivao je založnog vjerovnika na posjedovanje založene stvari i ubiranje plodova kako bi njima kompenzirao kamate na svoju tražbinu, što se i danas poima osnovnim oblikom ovoga instituta. ${ }^{9}$ Izgledan motiv za njegov nastanak pronalazimo u zabrani korištenja založenom stvari koja je inače postojala kao značajka položaja založnog vjerovnika (suprotno postupanje bilo bi furtum usus, krađu uporabe, i dovodilo založnog vjerovnika do omražene posljedice infamije, gubitka građanske

7 Pojmovi antichresis i pactum antichreticum izričito se spominju svega četiri puta u svim antičkim pravnim spisima, od toga jednom u grčko-egipatskom papirusu iz 2. stoljeća, dva puta u Marcijanovim odlomcima obuhvaćenim unutar Digesta i jednom u Palestinskom Talmudu. Slučajevi kasnije uporabe ovog pojma svi redom upućuju na odlomke Digesta. Prema Cohen, B., Jewish and Roman Law, A comparative study, The Jewish Theological Seminary of America, New York, Shulsinger Bros. Inc., 1966., str. 456.

8 Većina dvojbi o karakteristikama ovog/ovih instituta najvjerojatnije proizlazi iz njihova poistovjećivanja i uporabe termina antihreza i pactum antichreticum kao sinonima, iako je riječ o dva različita instituta, s bitno drukčijim funkcijama. Ideju o antihrezi i antihreznom paktu kao različitim institutima zagovara i Alegre de Miguel, koji tvrdi da razlog njihova poistovjećivanja vjerojatno proizlazi iz pogrešne interpretacije grčke riječi chresis koja se može tumačiti kao uporaba, ali isto tako i kao zajam, odnosno uzajamni zajam kada je riječ o antihrezi. Većina autora drži antihrezu vrstom zaloga ili paktom koji se može ugovoriti samo uz ugovor o zalogu. Taj oblik antihreze vezane za zalog može se prepoznati u Marcijanovom tekstu D.13.7.33. na temelju toga što se ovaj oblik antihreze, kao i založno pravo, štiti putem actio in rem. Međutim, tzv. „čistu“ antihrezu nalazimo u tekstu Marcijanova odlomka D.20.1.11.1. gdje je riječ o samostalnom ugovoru koji se štiti putem actio in factum. Ovaj oblik antihreze je samostalan ugovor kojim vjerovnik stječe plodove loco pignoris, a ne iure pignoris i zaštićen je putem actio in personam. Prema: Hernandez-Moreno, A., Antichresis o Contrarium Mutuum, Real Academia de Ciencias Economicas e Financieras, Barcelona, 2014., str. 110. Više Alegre de Miguel, J. D., op. cit., str. 12. Više o institutu antihreze u rimskom pravu Matić, I., Petranović, A., Antihreza u rimskoj pravnoj doktrini, Zbornik Pravnog fakulteta Sveučilišta u Rijeci, vol. 39, 3/2018, str. 1153-1168.

9 „Antikreza (grč. anti, kresis miješanje) prav. dopunski ugovor o zalogu po kojem založni vjerovnik, umjesto interesa na dug, ima pravo služiti se i koristiti založenim predmetom" prema Anić, Š., Klaić, N., Domović, Ž., Rječnik stranih riječi, Tuđice, posuđenice, izrazi, kratice $i$ fraze, Zagreb, SANI-PLUS, 2002., str. 90.

Romac definira antichresis kao „ugovor na temelju kojega je založni vjerovnik mogao upotrebljavati založenu stvar i pobirati plodove. Ovakav pravni posao predstavljao je odstupanje od zabrane uporabe i korištenja stvari (furtum usus) pa je stoga iznimno bio moguć samo kod plodonosnih stvari. Plodovi stvari su, uz pristanak založnog dužnika, zapravo namirivali kamate na dugovani iznos novca. Ukoliko se pak radilo o beskamatnom zajmu osiguranom zalogom plodonosne stvari, založni vjerovnik je mogao, po kasnijem pravu, i bez posebnog ugovora (tzv. pactum antichreticum) zadržati plodove do visine kamata uobičajenih u tom mjestu (antichresis tacita).“ Romac, A., Rječnik rimskog prava, Zagreb, Informator, 1975., str. 59. 
časti). ${ }^{10}$ Pactum antichreticum omogućivao je strankama sporazumjeti se drukčije i time omogućiti založnom vjerovniku da kroz prihode založene stvari koju drži u posjedu aktivno namiruje svoju svoje tražbinu i prije njezina dospijeća. Potvrdu teze o mogućnosti ugovaranja antihreznog pakta uz ugovor o zalogu nalazimo u predviđenoj pravnoj zaštiti koja u slučaju instituta pactum antichreticum znači ugovornu tužbu priznatog ugovora uz koji je uglavak dodan, to jest u primjeni actio pigneraticia ako se radi o paktu dodanom ugovoru o zalogu, što je najčešći slučaj. ${ }^{11}$ Osim uz ugovor o zalogu, ovaj pakt bio je moguć i uz bilo koji drugi ugovor. ${ }^{12}$ Funkcija antihreznog pakta bila je dvostruka i obuhvaćala je namirenje kamata ubranim plodovima, kao i osiguranje glavnice kroz posjedovanje nekretnine. Osnovna značajka pravnog režima ovoga pakta sastojala se u tomu da vjerovnik nije bio dužan izvješćivati dužnika o ubranim plodovima što mu je omogućivalo naplaćivanje (nesrazmjerno) visokih kamata, zbog čega je pactum antichreticum označen kao lihvarski institut i supstitut kamatama. ${ }^{13}$

Antihreza kao samostalni ugovor pojavljuje seu razdoblju postklasike, najvjerojatnije kao inominatni ugovor do ut facias, a koji zaključak se može utemeljiti na činjenici da se ovom pravnom odnosu zaštitu pruža putem actio in factum,tužbi predviđenoj odnosno korištenoj za pravnu zaštitu inominatnih kontrakata. ${ }^{14} \mathrm{Na}$

10 Potvrdu o tomu nalazimo u Gajevom odlomku D.47.2.55.(54).pr. si pignore creditor utuatur, furtum tenetur.

11 Marc. D.13.7.33. Si pecuniam debitor solverit, potest pignorat actione uti ad reciperandam antichresis: nam cum pignus sit, hoc verbo poterit uti. (Nakon što je dužnik isplatio dugovano, može putem actio pigneraticia tražiti povrat stvari dane $\mathrm{u}$ antihrezu, jer kada se radi o zalogu može se koristiti ova riječ.)

12 Manigk, A., Bullettino dell'istituto di Diritto Romano, Roma, Facoltá Giuridica della Roma Universitá, 1911., str. 259-262.

13 Doktrina je ostala podijeljena po pitanju je li pactum antichreticum iznimka od zabrane uzimanja kamata ili njihovog ograničenja. Načelno je prihvaćen stav da su plodovi (prihodi) nekretnine koji su premašivali iznos dugovanih kamata trebali biti vraćeni nazad dužniku kao višak (superfluum). Međutim, ako je bila ugovorena, tzv. čista antihreza, onda bi svi plodovi pripadali vjerovniku na ime kamata jer je on snosio rizik nastanka i opsega nastanka plodova (aleatornost) te nije mogao potraživati eventualnu razliku od dužnika ako nastali plodovi ne bi bili dostatni za namirenje njegove tražbine. Imperator Philippu. C.4.32.17. Si ea lege possessionem mater tua apud creditorem tuum obligavit, ut fructus in vicem usurarum consequeretur, obtentu maioris percepti emolumenti propter incertum fructuum eventum rescindi placita non possunt. (Ako je tvoja majka predala posjed vjerovniku uz klauzulu „plodovi će biti ubirani umjesto kamata“, takav dogovor ne može biti raskinut na temelju toga što je vjerovnik stekao veću korist, jer je urod plodova nesiguran.) Više u Thomas, P., Antichresis, Hemiolia and the Statutory Limit on Interest in Gerard Noodt's De foenore et usuris, De Jure, vol. 40, 1/2007, str. 52-68; Mirabelli, G., Dell'anticresi, Napoli, Editore Federico Corrado, 1888., str. 5-53; Van Niekerk, S. J., et al. (ur.), The Three Book on Interest - bearing Loans and Interest (Foenus et Usurae) by Gerard Noodt, Leiden, Pretoria University Law Press, 2009., str. 145; Bobbink, R., Antichresis: het vergeten zekerheidsrecht, Een historische vergelijking met het Franse recht, GROM 2016, on line publication, preuzeto s file://D:/Users/Ines/Downloads/28933-34063-1-SM\%20(2).pdf, 8. siječnja 2019.

14 Marc. D.20.1.11.1. si antichresis facta sit et in fundum aut in aedes aliquis inducatur, eo usque retinet possessionem pignoris loco, donec illi pecunia solvatur, cum in usuras fructus percipiat aut locando aut ipso percipiendo habitandoque: itaque si amiserit possessionem, solet in 
temelju ovog ugovora jedna strana prenosi vlasništvo određenog iznosa novca (činidba dare), a druga prenosi posjed nekretnine na određeni rok (činidba facere). ${ }^{15}$ Funkcija ugovora o antihrezi kao inominatnog ugovora je namirenje cjelokupne tražbine (kamata i glavnice) ubiranjem plodova nekretnine koja je predmet ugovora s funkcijom namirenja tražbine, a ne osiguranja tražbine. ${ }^{16} \mathrm{Za}$ razliku od značajke režima antihreznog pakta, u ugovoru o antihrezi vjerovnik je dužan podnositi obračun o ubranim plodovima nekretnine.

Pod snažnim utjecajem kanonskoga prava tijekom srednjeg vijeka kamate su bile zabranjivane kao nemoralne zbog stavova Crkve o neplodnosti novca, zbog toga 1163. godine zaslugom Pape Alexandra III. dolazi i do izričite zabrane ugovaranja antihreznog pakta te je određeno da se plodovima stvari ima namirivati samo glavnica. ${ }^{17}$ Međutim, zabrana je prouzročila postupno evoluiranje antihreznog pakta iz instituta koji služi kompenziranju isključivo kamata u institut čija je funkcija amortizacija cjelokupne tražbine (kamata $\mathrm{i}$ glavnice). ${ }^{18}$ Unatoč opisanom ostracizmu naspram ovog instituta u srednjem vijeku, pactum antichreticum bilježi praksa ius commune. ${ }^{19}$ Povratak antihreze i antihreznog pakta uočljiv je u građanskim kodifikacijama 19. stoljeća, za što je zaslužan Code civil des Français ${ }^{20}$ koji je prvi ponovno normirao

factum actione uti. (Ako bude zaključen ugovor o antihrezi, pa nekome bude predano zemljište ili zgrade, on sve dotle zadržava posjed na osnovi zaloga dok mu novac ne bude isplaćen, jer on prihode, bilo putem zakupa, bilo putem samostalne obrade odnosno stanovanja, uzima kao kamate; stoga mu, ako izgubi posjed, treba dopustiti actio in factum.)

15 Upravo zbog toga se dijelom $u$ doktrini rabi naziv recipročni ili uzajamni zajam (contrarium mutuum). „Prava“ antihreza, smatra Hernandez-Moreno, je ugovor koji je uzajamni, recipročni zajam gdje jedna strana prima određeni iznos novca, a druga prima u posjed nekretninu čije plodove ubire dok joj spomenuti iznos novca ne bude vraćen (fructus in vicem usurarum). Hernandez-Moreno, A., op. cit., str. 77.

$16 \mathrm{Za}$ razliku od instituta pactum antichreticum čija je funkcija kompenzacija plodova stvari isključivo s kamatama.

17 Navarro, I., Housing tenure, property rights and urban development in developing countries, Georgia Institute of Tehnology and Georgia State University, 2008., str. 5.

18 Ovakav oblik antihreznog pakta prijelazna je faza između rimskih instituta pactum antichreticum i ugovora o antihrezi te amortizacijske i kompenzacijske antihreze koju nalazimo u građanskim kodifikacijama koje se temelje na rimskom pravu. Više u Mousourakis, G., Roman Law and the Origins of the Civil Law Tradition, London, Springer, 2015., str. 287; Zimmermann, R., The New German Law of Obligations, Historical and Comparative Perspectives, New York, Oxford University Press, 2005., str. 5-39. O evoluciji kodifikacija u pravnim sustavima civilnog prava v. više: Murillo, M. L., The evolution of Codification in the Civil Law Legal Systems: Towards Decodification and Recodification, Journal of Transnational Law\&Policy, vol. 11, 1/2001, str. 1-20, Lachner, V., Roškar, J., Građanske kodifikacije u Europi s posebnim osvrtom na 19. i 20. stoljeće, Zbornik radova znanstvenog skupa Austrijski građanski zakonik (1811-2011), Tuzla, Pravni fakultet Univerziteta u Tuzli i Pravni fakultet Sveučilišta J.J. Strossmayera u Osijeku, 2013., str. 31-49.

19 Prednosti ovoga pravnog instituta prepoznali su i vitezovi templari koji su na taj način financirali svoje pohode: uzimali su zajmove i zauzvrat zalagali svoju zemlju uz pactum antichreticum koji je založnog vjerovnika ovlašćivao da ubire plodove tog zemljišta i tako namiruje svoje potraživanje. Prema Bobbink, R., op. cit., str. 88.

20 Code civil des Français usvojen je 1804. godine, a 1807. obnovljen pod imenom Code Napoleon (u daljnjem tekstu Francuski građanski zakonik). 
antihrezu. $^{21}$

\section{ANTIHREZA U SUVREMENOM KOMPARATIVNOM ZAKONODAVSTVU}

U ovome radu podastiru se ključne značajke režima instituta antihreze i pactum antichreticum sukladno zakonodavstvima Francuske, Španjolske i Italije te država Latinske Amerike, ${ }^{22}$ kao država koje reguliraju ovaj/ove institute i koje u svom pravnom sustavu imaju izraženu tradiciju rimskog prava, uvelike prepoznatljivu i u značajkama uređenja ovih instituta. Akcenti analize antihreze u krugu latinoameričkih država usmjereni su na praktične pokazatelje preuzimanja ovog antiknog instituta u aktualnim pravnim potezima i (uspješnom) promišljanju rješenja pojedinih gospodarskih problema ili poteškoća.

\subsection{Francuska}

Francuski Građanski zakonik poznavao je antihrezu kao vrstu zaloga na nekretninama - nantissement, ${ }^{23}$ čija je funkcija bila namirenje tražbine plodovima

21 Francuski građanski zakonik iz 1804. godine postavio je temelje za sve ostale građanske kodifikacije u Europi (talijansku, španjolsku), ali i Latinskoj Americi tijekom 19. stoljeća, što je uočljivo i u primjeru antihreze. Iako zakonici Latinske Amerike iz povijesnih razloga imaju usku povezanost sa španjolskim zakonodavstvom, ovaj utjecaj nije toliko izražen kada je riječ o institutu antihreze jer je većina ovih zakonika (osim Građanskog zakonika Brazila i Građanskog zakonika Kube) sastavljena prije nego Građanski zakonik Španjolske te se smatra da su utemeljeni na Francuskom građanskom zakoniku. U Francuski građanski zakonik antihreza je uključena na inzistiranje većine apelacijskih sudova koji su bili konzultirani tijekom izrade nacrta ovog zakonika, pod izraženim utjecajem rimskog prava. Uvođenje antihreze u Francuski građanski zakonik (s obzirom na njegov utjecaj na druge građanske kodifikacije) bilo je ključno za širenje ove ustanove u moderna zakonodavstva. Za reguliranje antihreze posebno su se zalagali sudovi u Bordeauxu, Aixu, Grennobleu, Limogesu, Lyonu, Nimesu i Parisu uz prijedlog da bude uređena kao vrsta nantissement instituta, tj. kao zalog na nekretninama. Svoj su stav argumentirali praksom koja je postojala u nekim dijelovima Francuske, posebice u onim dijelovima koji su imali i pisane zakone, a koji su poznavali zalog nekretnina kao ugovor koji se sklapa pod imenom antihreza. Prema Hernandez-Moreno, A., op. cit., str. 85-88; Alegre de Migule, J. D., op. cit., str. 20.

22 Od dvadeset analiziranih građanskih zakonika država Latinske Amerike samo pet zakonika ne uređuje ovaj institut. Riječ je o Građanskom zakoniku Kube (razlog izostanka povezan je s općenitom zabranom zajmova uz kamate i bilo kakvih pravnih poslova koji su povezani $\mathrm{s}$ kamatama), dok je antihreza brisana iz građanskih zakonika Paragvaja, Meksika, Gvatemale i Kostarike. Iako Građanskim zakonikom Paragvaja nije regulirana, antihreza je raširena u praksi te se ugovara kao inominatni ugovor; kada je riječ o Gvatemali, unatoč činjenici da je antihreza brisana iz Građanskog zakonik Gvatemale, doktrina se zalaže za ponovno uvođenje ovog instituta.

23 Pothier je smatrao kako je nantissement institut različit od antihreze. Po Pothieru, nantissement je garancija koja se sastoji u tomu da se vjerovniku preda pokretna ili nepokretna stvar, $\mathrm{s}$ mogućnošću da on tu stvar zadrži ili da je proda, kao i da od nje ubire plodove kako bi namirio svoje potraživanje. Pothier je branio tezu da je hipoteka garancija po civilnom pravu, dok je nantissement garancija po ius gentium. Prema Lovera, M., El contrato de anticresis, Caracas, 
stvari, a založnom vjerovniku je ovaj pravni režim davao i ovlaštenja ius distrahendi i ius prelationis, s obzirom na to da je bila uređena kao vrsta založnog prava na res immobiles. Izmjenama iz 2009. godine iz zakonika nestaje naziv antihreza, ali se zadržava istovjetan sadržaj pravnog instituta koji se sada naziva zalog nekretnina (la gage immobilier). ${ }^{24} \mathrm{Za}$ razliku od hipoteke, koju ovaj zakonik također poznaje i uređuje kao neposjedovno založno pravo na nekretnini, institut zaloga nekretnina (to jest antihreza) uključuje ovlaštenje posjedovanja i plodouživanja založene nekretnine u cilju namirenja. Time je francuski zakonodavac, unatoč promjeni nazivlja, zadržao bit sadržaja instituta antihreze čime je očigledno prepoznat potencijal instituta koji omogućuje maksimalno iskorištavanje vrijednosti nekretnine pružajući tom (antihreznom) založnom vjerovniku ius possidendi, ius fruendi, ius distrahendi, ius retentionis, ius prelationis i zaštitu erga omnes. ${ }^{25}$

\section{2. Španjolska i Italija}

Za razliku od francuske regulative u kojoj antihreza, to jest zalog nekretnina, odnosno stvarno pravo na tuđoj stvari ima jasna obilježja i učinke, u zakonodavstvima Španjolske i Italije režim ovog instituta nije toliko prepoznat i obrađen (iako su zakonici rađeni po uzoru na francuski) te je upravo pravna nesigurnost alternativnih tumačenja koja nastaju kao posljedica nepreciznosti zakonodavstva vjerojatno jedan od razloga zanemarivanja antihreze u praksi. Razlog zajedničke (usporedne) analize ova dva pravna poretka velika je sličnost njihova uređenja antihreze.

I u talijanskom ${ }^{26} \mathrm{i}$ u španjolskom ${ }^{27}$ zakonodavstvu pronalazimo kompenzacijsku i amortizacijsku antihrezu. Kompenzacijska antihreza ima svoj temelj u rimskom institutu pactum antichreticum i pakt je koji omogućuje vjerovniku ubiranje plodova nekretnine na ime kamata, u cilju njihova potpunog ili djelomičnog namirenja tijekom trajanja ugovora. ${ }^{28}$ Ovakav sporazum stranaka vjerovnika oslobađa obveze

Universidad Católica Andrès Bello, 1993., str. 8; Tedeschi, V., L’Anticresi, Torino, Unione Tipografico - Editrice Torinese, 1952., str. 10.

24 Francuski građanski zakonik, članak 2387.: Le gage immobilier est l'affectation d'un immeuble en garantie d'une obligation; il emporte dé possession dece lui qui le constitue.

25 Ovakav način uređenja jedinstven je u Europi i zapravo je sličniji značajkama instituta u državama Latinske Amerike koje su, uostalom, za uzor oduvijek imale francuski pravni model stoga inkliniranje takovim rješenjima ne iznenađuje. Bolivija, Haiti i Dominikanska Republika antihrezu smatraju posjedovnim zalogom nekretnina. Više Matić, I., Pactum antichreticum, doktorska disertacija, Pravni fakultet u Rijeci, Rijeka, 2017., str. 187-235.

26 Il Codice Civile Italiano, Gazzetta Ufficiale, $n$. 79 del 4 aprile 1942, ultimo aggiornamento: marzo 2000 (u daljnjem tekstu Građanski zakonik Italije).

27 Código Civil Español, 25 de julio de 1889, última modificación: 6 de octubre de 2015 (u daljnjem tekstu Građanski zakonik Španjolske).

28 Građanski zakonik Italije, članak 1964.: È valido il patto col quale le parti convengono che i frutti si compensino con gli interessi in tutto o in parte. In tal caso il debitore può in ogni tempo estinguere il suo debito e rientrare nel possesso dell >immobile.

Građanski zakonik Španjolske, članak 1885.: Los contratantes pueden estipular que se compensen los intereses de la deuda con los frutos de la finca dada en anticresis.

Ubiranje plodova nekretnine tumači se u širem smislu i podrazumijeva korištenje nekretninom na bilo koji način koji nije protivan njezinoj ekonomskoj svrsi, što je podrazumijevalo već i 
podnošenja izvješća, tj. obračuna o vrijednosti ubranih plodova. ${ }^{29} \mathrm{U}$ pravnom okviru kompenzacijske antihreze rizik realizacije plodova nekretnine prebacuje se na antihreznog vjerovnika jer se učinak kompenzacije plodova s kamatama ostvaruje neovisno o tomu je li nekretnina ostvarila plodove ili nije. Ako plodovi u cijelosti izostanu, smatra se da vjerovnik nema pravo na kamate. Međutim, to ne znači da antihrezni vjerovnik tada snosi i troškove održavanja te nekretnine jer ih ima pravo namiriti iz ostvarenih plodova, a ako plodovi nisu dostatni, nadoknadu troškova može tražiti tužbom. Kako bi se zaštitilo dužnika i onemogućilo da vjerovnik ostvaruje koristi koje bi se mogle smatrati lihvarskim kamatama omogućuje se dužniku ranije ispuniti svoju obvezu, protivno volji antihreznog vjerovnika i tako u bilo koje doba vratiti nekretninu pod svoje upravljanje. ${ }^{30}$

Amortizacijska antihreza je ugovor kojim se dužnik ili treća osoba obvezuje predati nekretninu vjerovniku radi osiguranja njegove tražbine, tako da vjerovnik ubire plodove te nekretnine i obračunava ih te prebija s kamatama (ako su ugovorene), odnosno glavnicom potraživanja. ${ }^{31}$ Vjerovnik je obvezatan podnositi obračune o

rimsko pravo sukladno Marcijanovom odlomku D.20.1.11.1 ... aut locando, aut ipse percipiendo habitandoque. V. više Tedeschi, V., op. cit., str. 19.

Kompenzacijska antihreza definira se kao pakt kojim stranke mogu ugovoriti da ubiranje plodova nekretnine koja je predmet ugovora služi isključivo za kompenzaciju s kamatama, što znači da niti u jednom trenutku ubiranjem plodova neće doći do amortizacije glavnice pa nema niti funkciju osiguranja namirenja. Ne ovlašćuje antihreznog vjerovnika na ius distrahendi. Učinak kompenzacijske antihreze kompenzacija je dugovanih kamata s ubranim plodovima $\mathrm{i}$ retencija nekretnine do potpune isplate pozajmljenog iznosa.

29 Openheim, L., Antichresis: an ancient security device revived (Editorial-Comments, T. L. R. 1938), Tulane Law Review, vol. 13/1938, str. 133-134; Cicero, C., Il Codice Civile, Commentario, Giuffre Editore, Milano, 2010., str. 14; Giuffrè, R., Di taluni contratti trascurati: il mandato di credito e l'anticresi, Corriere giuridico, 1/2012, str. 34-39; Fragali, M., Commentario del Codice civile, Libro quarto, Delle obbligazioni, art. 1960 - 1991, Bologna, Nicola Zanichelli, 1974., str. 7.

30 Građanski zakonik Italije, članak 1185., stavak 1.: Il creditore non può esigere la prestazione prima della scadenza, salvo che il termine sia stabilito esclusivamente a suo favore.

31 Građanski zakonik Italije, članak 1960.: L'anticresi è il contratto col quale il debitore o un terzo si obbliga a consegnare un immobile al creditore a garanzia del credito, affinchè il creditore ne percepisca i frutti, imputandoli agli interessi, se dovuti, e quindi al capitale. Iako je talijanski Codice Civile inspiriran Francuskim građanskim zakonikom prema kojem je antihreza vrsta založnog prava na nekretninama, talijanski zakonodavac čini znatan odmak i regulira antihrezu kao ugovor koji služi osiguranju svih vrsta tražbina, tj. ugovor kojim se dužnik ili treća osoba obvezuje predati nekretninu vjerovniku radi osiguranja njegove tražbine, tako da vjerovnik ubire plodove te nekretnine i obračunava ih kamatama, ako su ugovorene, odnosno glavnici potraživanja.

Građanski zakonik Španjolske, članak 1881.: Por el anticresis el acreedor adquiere el derecho de percibir los frutos de un inmueble de su deudor, con la obligación de aplicados al pagado se los intereses, si se debieren, y después al del capital de su credito. Amortizacijska antihreza španjolskog prava je konsenzualan ugovor sinalagmatičnog karaktera za koji nije potrebna nikakva posebna forma. Ugovor o amortizacijskoj antihrezi ovlašćuje antihreznog vjerovnika na posjedovanje nekretnine koja je predmet ugovora i ubiranje njezinih plodova na ime kamata, a zatim i glavnice, sve do potpunog namirenja, s obzirom na to da maksimalno trajanje ovog ugovora nije ograničeno Zakonikom. Iznimno važno je naglasiti da ovaj Zakonik čini jasnu razliku između instituta antihreze i pactum antichreticum, što ukazuje na duboku ukorijenjenost 
ubranim plodovima, njihovoj vrijednosti i prebijanju radi namirenja kamata i glavnice, što sprječava manipulacije i mogućnost prikrivanja zelenaškog i nemoralnog ili nezakonitog ugovora.Za razliku od kompenzacijske antihreze izraženoga aleatornog karaktera, kod amortizacijske antihreze aleatornost je u potpunosti isključena jer je vjerovnik dužan podnijeti obračun o ubranim plodovima i njima namirivati i kamate i glavnicu. ${ }^{32}$

Pravna priroda prava koje nastaje na temelju ugovora o antihrezi jedno je od pitanja koje izaziva prijepore u doktrini jer ni Građanski zakonik Italije ni Građanski zakonik Španjolske ne definiraju izričito pravnu prirodu prava koje nastaje ugovorom o antihrezi. U Italiji je prevladavajuće stajalište da na temelju ugovora o antihrezi antihrezni vjerovnik stječe osobno pravo uživanja, a ne stvarno pravo, odnosno da ovaj pravni posao spada u skupinu pravnih poslova intuitu personae. ${ }^{33}$ Talijanska doktrina uglavnom ima stajalište da je antihreza personalno pravo uživanja nekretnine, unatoč tomu što postoje i mišljenja o njenom stvarnopravnom karakteru. ${ }^{34} \mathrm{~S}$ druge strane, općeprihvaćen stav španjolske doktrine je taj da je antihreza vrsta stvarnopravnog osiguranja tražbine, jednako kao hipoteka i zalog. ${ }^{35}$ Međutim, argumentaciju za takav

rimske pravne misli u španjolskom pravnom sustavu.

32 Vjerovnik je dužan obračunati ubrane plodove te za njihovu vrijednost umanjiti kamate i glavnicu. Upravo to sprječava lihvarske postupke zabranjene zakonom. Hernandez-Moreno, A., op. cit., str. 54, Alegre de Miguel, J. D., op. cit., str. 78.

33 Više u Camonita, S., L'anticresi e la garanzia del credito, preuzeto s www.diritto.it, objavljeno 23.02.2012.

34 Teza o personalnom karakteru antihreze bila je potvrđena i građanskim kodifikacijama 19. stoljeća (Francuski građanski zakonik, članak 2091.; talijanski Codice Civile iz 1865. godine, članak 1897.) koji su izričito propisivali da antihreza ima učinak samo među ugovornim stranama i njihovim nasljednicima. O stvarnopravnom i obveznopravnom učinku antihreze V. Fragali, M., op. cit., str. 8-9; Cicero, C., op. cit., str. 17-20. Činjenica je da zbog transkripcije antihreza djeluje i prema trećima. Također, ne možemo osporiti da je odnos antihreznog vjerovnika prema stvari neposredan, što je inače karakteristika stvarnih prava. Osim toga, antihrezu karakterizira pravo slijeđenja i neodvojivost od nekretnine koja je objekt antihreze, što sve dovodi u sumnju kategorizaciju antihreze kao personalnog prava. Macario se zalaže za tezu o antihrezi kao stvarnom pravu: na tragu prethodno navedenih argumenata navodi kako uvrštavanje antihreze među ugovore za koje se zahtijeva transkripcija (članak 2643., stavak 12. Građanski zakonik Italije) i posljedično pravo slijeđenja koje stječe antihrezni vjerovnik, kao i mogućnost da njegovo pravo ima učinka prema trećim osobama koje bi se mogle naći u nekom pravnom ili faktičnom odnosu naspram stvari koja je predmet antihreze, argumenti su koji govore u prilog tezi koja svrstava antihrezu u stvarna prava (Macario, F., Dei singoli contratti (art. 1861 - 1986), Torino, Utet Giuridica, 2009., str. 638). Cicero ističe kako transkripcija nije urođena posljedica prava na nekretnini i apsolutno djelovanje stvarnih prava nije nužno karakteristika stvarnih prava, već je ono povezano publikacijom istih putem transkripcije. Osim toga, neposredni odnos antihreznog vjerovnika naspram nekretnine koja je predmet antihreze usporediv je s onim koji ima najmoprimac ili komodatar, koji imaju stvar u detenciji, a ne u posjedu. S pravne točke gledišta, vlasnik nekretnine u antihrezi i dalje ostaje posjednik te nekretnine, pa se ne radi niti o neposrednosti odnosa u tehničkom smislu. Cicero, C., op. cit., str. 19.

35 Za razliku od Građanskog zakonika Španjolske, Građanski zakonik Katalonije izričito definira antihrezu kao stvarnopravno osiguranje tražbine, koje karakterizira prijenos posjeda nekretnine na vjerovnika, kao i ius distrahendi, dok Građanski zakonik Španjolske ne govori ništa izričito. Više Lovera, M., op. cit., str. 16; Alegre de Miguel, J. D., op. cit., str. 79-82. 
zaključak procjenjujemo ranjivom s obzirom na to da Građanski zakonik Španjolske ne propisuje izričito da na temelju ugovora o antihrezi nastaje stvarno pravo, niti ovlašćuje antihreznog vjerovnika na ius distrahendi, ius praelationis te stvarnopravnu zaštitu. Upravo iz navedenih razloga mišljenja smo da antihreza španjolskog zakonodavstva ima prevladavajuće značajke personalnog, a ne stvarnog prava te je u tom pogledu vrlo slična institutu antihreze u Građanskom zakoniku Italije.

Ako je riječ o predmetu ugovora o antihrezi, oba zakonika propisuju da to mogu biti samo nekretnine. ${ }^{36}$ Moguće je da predmet ovog ugovora bude i nekretnina koja je već u najmu, sve dok je antihrezni vjerovnik taj koji ubire prihode od toga ugovora kao oblik civilnih plodova. S obzirom na to da je riječ o pravu neraskidivo vezanom za korištenje nekretnine koja je predmet ugovora, i talijansko i španjolsko pravo, predviđaju registriranje ugovora o antihrezi u odgovarajući javni registar nekretnina kako bi se publicitetom omogućilo djelovanje erga omnes, unatoč tomu što time ne nastaje stvarno pravo za antihreznog vjerovnika. ${ }^{37}$

Svrha amortizacijske i kompenzacijske antihreze obuhvaća uživanje nekretnine u cilju osiguranja, ali i namirenja vjerovnikova potraživanja. Istodobno s funkcijom osiguranja, a možda i s većim značajem, antihreza ima satisfikatornu funkciju jer je poseban modalitet plaćanja bez provođenja neke posebne aktivnosti dužnika, već izravnim i neposrednim prisvajanjem koristi od nekretnine od strane vjerovnika.

Dok španjolski zakonodavac ne ograničava trajanje antihreznog ugovora, maksimalno trajanje ugovora o antihrezi u talijanskom pravnom poretku određeno je kogentnom pravnom normom na rok od deset godina (s tim što stranke nemaju mogućnost ugovoriti trajanje koje bi premašivalo ovaj rok, ${ }^{38}$ cilj je ove odredbe očigledno intencija maksimalnog skraćivanja razdoblja u kojem je vlasnik nekretnine lišen posjeda iste). ${ }^{39}$

36 Građanski zakonik Italije, članak 1961.: (1) Il creditore, se non è stato convenuto diversamente, è obbligato a pagare i tributi e i pesi annui dell'immobile ricevuto in anticresi. (2) Egli ha l'obbligo di conservare, amministrare e coltivare il fondo da buon padre di famiglia. Le spese relative devono essere prelevate dai frutti. (3) Il creditore, se vuole liberarsi da tali obblighi, può, in ogni tempo, restituire l'immobile al debitore purché non abbia rinunziato a tale facoltà. Građanski zakonik Španjolske, članak 1881. (cit. bilj. 32)

37 Građanski zakonik Italije, članak 1530., stavak 7.: Devono farsi per atto pubblico o per scrittura privata, sotto pena di nullità: ... 7) $i$ contratti di anticresi...

Građanski zakonik Italije, članak 2643.: Si devono rendere pubblici col mezzo della trascrizione:... 12) i contratti di anticresi... Obveza transkripcije ne smatra se preduvjetom za valjanost ugovora, te antihreza koja nije s transkripcijom ima valjanost među strankama. Ona postoji kao forma, postupak, kako bi antihreza stekla učinak i prema nekim trećim osobama. U tom smislu, možemo razlikovati antihrezu koja ima samo obveznopravne učinke, među strankama i antihrezu sa stvarnopravnim učincima prema određenim trećim osobama. Cicero, C., op. cit., str. 50.

38 Građanski zakonik Italije, članak 1962.: (1) L'anticresi dura finché il creditore sia stato interamente soddisfatto del suo credito, anche se il credito o l'immobile dato in anticresi sia divisibile, salvo che sia stata stabilita la durata. (2) In ogni caso l'anticresi non può avere una durata superiore a dieci anni. (3) Se è stato stipulato un termine maggiore, questo si riduce al termine suddetto.

39 Prema Persico, G., Anticresi, u: Enciclopedia del Diritto, vol. II, Milano, Giuffre Editore, 1958., str. 532. 
Obveze i prava antihreznog vjerovnika u talijanskom i španjolskom zakonodavstvu slično su uređene, pa tako antihrezni vjerovnik ima pravo ius possidendi i ius fruendi ${ }^{40}$ što je ujedno i bit njegova prava antihreze. ${ }^{41}$ Ubiranje plodova nije samo pravo već i obveza vjerovnika i pri upravljanju nekretninom mora se voditi kriterijima pažnje dobrog gospodarstvenika. ${ }^{42}$ Dužan je plaćati poreze i naknade te nužne troškove održavanja i popravaka nekretnine, ali može te troškove namiriti iz njezinih plodova ${ }^{43}$ Treba istaknuti kako antihrezni vjerovnik nema autonomiju glede vršenja svog prava ius fruendi, budući da svi ubrani plodovi moraju biti usmjereni na ispunjenje ugovorne obveze. ${ }^{44}$ Obvezatan je plaćati godišnje poreze i druge troškove nekretnine, kao i održavati nekretninu, upravljati njome i pobrinuti se da stvara plodove, podnositi dužniku račun o upravljanju nekretninom, vratiti nekretninu dužniku po prestanku antihreze, zajedno s plodovima koje je eventualno ubrao nakon namirenja. ${ }^{45}$ Antihrezni vjerovnik ovlašten je i osobno koristi nekretninu koju drži u antihrezi kada se takva uporaba može smatrati plodovima. ${ }^{46}$

40 Odredba članka 1960. Građanskog zakonika Italije izričito predviđa ubiranje plodove nekretnine od strane antihreznog vjerovnika, što znači da sama separacija naturalnih plodova, odnosno dospijeće civilnih plodova nisu dostatni za njihovo stjecanje, već je potrebno njihovo ubiranje (fructus percepti).

41 Iako članak 1960. Građanskog zakonika Italije govori o „predaji nekretnine u posjed“ antihreznog vjerovnika, on nad nekretninom u antihrezi ima detenciju ili pravo na detenciju, ali ne i posjed. Govorimo o detenciji jer je riječ o faktičnom držanju stvari koje sadrži samo corpus, ali ne i animus possidendi. Antihrezni vjerovnik drži stvar samo u ime onoga koji mu je tu stvar predao. Međutim, riječ je o kvalificiranoj detenciji kojoj zakon pruža zaštitu putem dvije različite posjedovne tužbe: tužba radi povrata u prijašnje stanje u slučaju posjeda oduzetog nezakonito ili silom (članci 1168. i 1169. Građanskog zakonika Italije) te tužba radi zaštite od smetanja posjeda (članak 1170.). Kako naglašava kasacijski sud u presudi br. 561 od 7.03.1851., antihrezni vjerovnik stječe detenciju nekretnine te ima ulogu prekarista. Prema Nicita, F. P., Giurisprudenza sistematica civile e commerciale, Anticresi, Unione tipografico Editrice Torinese, 1968., str. 290; Cicero, C., op. cit., str. 41.

42 Mecenate, F., L'anticresi, Una possible alternativa per il mercato immobiliare e per l'accesso al credito, Gazzetta Notarile, 7/9/2014, str. 3; Cicero, C., op. cit., str. 66.

$43 \mathrm{~S}$ obzirom na to da je riječ o odredbi dispozitivnoga karaktera, stranke mogu ugovoriti i drukčije. Međutim, ako troškovi nekretnine prelaze vrijednost koju antihrezni vjerovnik stječe od ubranih plodova, nema mogućnost istaknuti taj prigovor i tako se osloboditi svoje obveze. $\mathrm{U}$ tom slučaju jedina mogućnost koju antihrezni vjerovnik ima odustajanje je od ugovora $\mathrm{i}$ vraćanje nekretnine dužniku.

$44 \mathrm{Za}$ ispunjenje ugovorne obveze obračunavaju se neto plodovi nakon namirenja troškova održavanja nekretnine koje je predujmio antihrezni vjerovnik. Uzevši u obzir da ova obveza predujma plaćanja troškova ima zakonski karakter po Građanskom zakoniku Španjolske potrebno je odrediti da u trenutku povrata vjerovniku iznosa koji je unaprijed uplatio, nije moguće zahtijevati kamate. Radi se o rješenju drukčijem nego u Građanskom zakoniku Katalonije, gdje vjerovnik plaća samo ako to nije učinio onaj koji je prvotno obvezan, tj. vlasnik.

45 Cicero, C., op. cit., str. 62; Fragali, M., op. cit., str. 126. Obveza vraćanja nekretnine, kao i obveza vraćanja viška plodova koje je vjerovnik ubrao nakon namirenja svog potraživanja, nisu obveze iz ugovora o antihrezi, već one proizlaze iz činjenice da je ugovor prestao pa daljnje uživanje nekretnine i ubiranje plodova nemaju kauzu.

46 Građanski zakonik Italije, članak 1960. (cit. bilj. 32) dopušta osobno korištenje nekretnine. Međutim, postavlja se pitanje može li antihrezni vjerovnik zaključiti ugovor o najmu nekretnine 
Uz pravo ubiranja plodova, ius fruendi, antihrezni vjerovnik sukladno španjolskom pravu ima i pravo zadržanja, ius retentionis, kao jedan od osnovnih elemenata antihreze, ${ }^{47}$ kao i ius distrahendi ${ }^{48}$ dok antihrezni vjerovnik u talijanskom pravnom poretku nema ius distrahendi niti ius prealationis, ${ }^{49}$ ali antihreza koja je

koja je predmet antihreze s antihreznim dužnikom jer u tom slučaju antihrezni dužnik zadržava pravo uživanja nekretnine, samo uz obvezu da plati najamninu za vlastitu nekretninu, čime antihrezni vjerovnik ostvaruje indirektno uživanje nekretnine putem antihreznog dužnika. Zapravo time antihrezni vjerovnik kroz rate najamnine dužnikove nekretnine namiruje svoju tražbinu. Na isti način su onda antihrezni vjerovnik i antihrezni dužnik mogli zaključiti ugovor o zajmu uz obročnu otplatu. Ovakav oblik transakcije ima smisla jedino ako se načelno ugovara beskamatni zajam, a onda se kroz najamnine za nekretninu prikrivaju kamate. Zanimljivo razmišljanje o ovom pitanju podastire Tedeschi koji tvrdi da se ne radi o antihrezi kada antihrezni vjerovnik nekretninu koja je predmet antihreze da u najam istoj toj osobi koja mu je predala nekretninu u antihrezu. Suprotno zaključuju Mirabelli i Fragali koji posebice brane mogućnost antihreznog vjerovnika da svoje uživanje nekretnine ostvaruje i indirektno, putem antihreznog dužnika kojem daje nekretninu u najam. Tedeschi, V., op. cit., str. 66; Fragali, M., op. cit., str. 61.

47 Prema Alegre de Miguelu se u ovom slučaju radi o antihreznom zadržanju, tj. o zadržanju koje slijedi iz toga što je antihreznom vjerovniku priznato stjecanje plodova ubiranjem istih, a antihrezni ius retentionis nastupa kada tražbina na ime glavnice i/ili kamata nije ispunjena po dospijeću. Kada retencija ima svoj izvor u potraživanjima na temelju troškova upravljanja, održavanja i ostalih troškova glede nekretnine, antihrezni vjerovnik ima redovito pravo zadržanja tijekom kojega može prihod nekretnine koristiti za podmirenje tih potraživanja. Ti plodovi izvorno pripadaju vlasniku ili drugom titularu nekretnine, ali ih može zadržati vjerovnik kako bi namirio ta potraživanja.

48 Pitanje ovlaštenja ius distrahendi jedno je od najkompleksnijih pitanja uređenja antihreze u španjolskom pravnom sustavu. Mišljenja smo da antihrezni vjerovnik nema navedena ovlaštenja te je činjenica da doktrina zastupa drukčiji stav ujedno jedan od nedostataka španjolske antihreze jer dovodi do pravne nesigurnosti i visokog rizika u poduzimanju ovoga pravnog posla, zbog čega on vjerojatno i nestaje iz uporabe u praksi. Problem proizlazi iz činjenice da Građanski zakonik Španjolske ovlašćuje antihreznog vjerovnika isključivo na pokretanje redovitog ovršnog postupka kako bi namirio svoju tražbinu (glavnica i/ili kamate) ako je nije uspio namiriti kroz ugovor o antihrezi. Međutim, doktrina priznaje antihreznom vjerovniku pravo zatražiti direktnu sudsku prodaju nekretnine koja je predmet ugovora (ius distrahendi) te u tako realiziranoj prodaji nekretnine antihrezni vjerovnik ima ius praelationis, pravo prvenstva namirenja iz cijene ostvarene prisilnom prodajom. Navedeno bi bilo i vrlo logično ako je polazište poimanje antihreze kao stvarnog prava, a ius distrahendi jedno od uobičajenih ovlaštenja stvarnih prava. Međutim, iako doktrina pripisuje antihreznom vjerovniku ius distrahendi i ius praelationis, kao i karakter stvarnog prava, prepreku tome nalazimo u članku 1884. kojim se uređuje ius distrahendi i ius praelationis, a ne odnosi se na antihrezu te u članku 1923. Građanskog zakonika Španjolske, kojim je definiran redoslijed namirenja vjerovnika u slučaju prisilne prodaje, a antihreza nije predmetom uređenja ovog članka. Prema Alegre de Miguel, J. D., op. cit., str. 400 et seq. U prilog tvrdnji da antihrezni vjerovnik nema pravo na direktnu prodaju nekretnine govori i presuda Tribunal Supremo, Sala de lo Contencioso, Madrid, STS 497/2016, od 16. veljače 2016. Ovu tezu dodatno potvrđuje Hernandez-Moreno, A., op. cit., str. 161: „Tradicionalno se pruža pogrešna interpretacija pravne i ekonomske funkcije antihreze pa predanost kojom Španjolska želi priznati (iako nije izričito propisano) antihrezi i ovlaštenje na namirenje iz vrijednosti nekretnine koja je predmet ugovora u cijelosti je unakazila svrhu instituta, izazivajući bez sumnje izostanak uporabe ovog instituta u praksi.“ Tedeschi, V., op. cit., str. 94-95. 
transkripcijom zabilježena u registru može imati prednost pri namirenju u odnosu na ostale vjerovnike na temelju ranijeg upisa ugovora o antihrezi u registar nekretnina, sukladno načelu prior tempore potior iure. Strankama je izričito zabranjeno ugovoriti pactum commissorium te se svaki sporazum stranaka suprotan ovoj odredbi smatra ništetnim i u španjolskom ${ }^{50}$ i u talijanskom pravu. ${ }^{51}$

Nekretninu u antihrezu može dati dužnik, kao i neka treća osoba. ${ }^{52}$ Potrebno je da osoba koja daje stvar u antihrezu bude vlasnik nekretnine ili ovlaštenik nekoga stvarnog prava uživanja. ${ }^{53}$ Antihrezni dužnik ovlašten je nekretninu koju je dao u antihrezu opteretiti i hipotekom. ${ }^{54}$ Također, ima pravo zahtijevati od antihreznog vjerovnika da upravlja nekretninom pažnjom dobroga gospodarstvenika, vodeći računa o njenoj ekonomskoj svrsi i maksimalnoj profitabilnosti i u protivnome zahtijevati povrat posjeda nekretnine. Međutim, ako antihrezni vjerovnik savjesno izvršava svoje obveze upravljanja nekretninom i podnošenja obračuna, antihrezni dužnik nije ovlašten tražiti povrat posjeda nekretnine sve dok u cijelosti ne ispuni svoju obvezu. ${ }^{55}$ Konačno, po prestanku ugovora o antihrezi, bilo istekom roka ili prestankom glavne obveze, antihrezni dužnik ovlašten je potraživati posjed nekretnine.

50 Građanski zakonik Španjolske, članak 1884: (1) El acreedor no adquiere la propiedad del inmueble por falta de pago de la deuda dentro del plazo convenido. (2) Todo pacto en contrario será nulo. Pero el acreedor en este caso podrá pedir, en la forma que previene la Ley de Enjuiciamiento Civil, el pago de la deuda o la venta del inmueble.

51 Zanimljivo je istaknuti da Građanski zakonik Italije, sadrži odredbu o zabrani pactum commissorium u članku 2744., no zakonodavac je očigledno smatrao potrebnim posebno istaknuti tu zabranu još jednom kada je riječ o antihrezi. Zabrana propisana članak 2744. te članak 1963. proširuje se i na bilo koji drugi pravni posao kojim se nastoji ostvariti isti učinak, tj. zaobilaženje propisane zabrane. Macario, F., op. cit., str. 670; Mastropaolo F., L'anticresi come contratto costitutivo di garanzia consistente in poteri su cose immobili, Rivista di diritto civile, vol. 50, 5/2004, str. 742 .

52 U slučaju zasnivanja antihreze neke treće osobe koja nije dužnik u glavnom odnosu, primjenjuju se odredbe članka 1180. Građanskog zakonika Italije o ispunjenju treće osobe. Za zasnivanje antihreze treće osobe u korist dužnika, nije potreban pristanak dužnika, ali se on može usprotiviti.

53 Antihrezu prema tome može zasnovati i suvlasnik, plodouživatelj, emfiteuta, čak i posjednik pro herede. S druge strane, ne može zasnovati antihrezu ovlaštenik prava uporabe ili stanovanja, kao ni najmoprimac, imajući u vidu strogo osobnu prirodu tih prava. Više Persico, G., op. cit., str. 535; Tedeschi, V., op. cit., str. 45; Fragali, M., op. cit., str. 27; Cicero, C., op. cit., str. 30; Alegre de Miguel, J. D., op. cit., str. 186.

54 Tedeschi smatra dopustivom kumulaciju to jest mogućnost da za istu tražbinu i istu nekretninu postoji paralelno osiguranje hipotekom i antihrezom. Navodi kako je u tom slučaju uloga hipoteke osiguranje glavnice, a uloga antihreze osiguranje naplate potraživanja kamata. Slično razmišljaju Butera i Fragali (Fragali primjećuje da to što je ovakvo ugovaranje uobičajeno istodobno ne znači da je nužno). Ako antihreza nije ograničena samo na kompenzaciju kamata, odnosi se i na namirenje glavnice, kao i ako hipoteka nije ograničena na glavnicu, pa se odnosi i na kamate. Prema Nicita, F. P., op. cit., str. 264.

55 Građanski zakonik Španjolske, članak 1883., stavak 1.: El deudor no puede readquirir el goce del inmueble sin haber pagado antes enteramente lo que debe a su acreedor. 


\subsection{Latinska Amerika}

Uređenju antihreze u državama Latinske Amerike posvećena je posebna pozornost budući da praksa latinoameričkih država svjedoči da antihreza ne mora biti percipirana kao relikt prošlosti te ukazuje na mogućnost uporabe ovog instituta za rješavanje postojećih pravnih, praktičnih i društvenih problema. $\mathrm{S}$ obzirom na to da pravne poretke Latinske Amerike možemo poimati jednim pravnim sustavom, ${ }^{56}$ istraživanjem je obuhvaćeno svih petnaest latinoameričkih zakonodavstava koja različito reguliraju ovaj institut, nudeći ujedno i potpuno novi praktični aspekt uporabe ugovora o antihrezi koji se u nekim zakonodavstvima svojim značajkama približava ugovoru o najmu, to jest primjenjuje se kao alternativa tom ugovoru zbog određenih prednosti koje antihrezu čine atraktivnijom. ${ }^{57}$

Od petnaest zakonodavstava Latinske Amerike koja uređuju antihrezu, samo Ekvador regulira isključivo amortizacijsku antihrezu, dok sve ostale države reguliraju amortizacijsku i kompenzacijsku antihrezu (kao i Španjolska i Italija). Zakonodavstvo Bolivije, Perua, Argentine, Brazila, Hondurasa, Nikaragve, Paname, Haitija te Dominikanske Republike propisuje da na temelju ugovora o antihrezi nastaje stvarno pravo antihreze, kao stvarno pravo na tuđoj stvari (iura in re aliena). Štoviše Bolivija, ${ }^{58}$ Haiti $^{59}$ i Dominikanska Republika ${ }^{60}$ antihrezu smatraju, po uzoru na Francusku, vrstom založnog prava, to jest zalogom nekretnina. Zakonici Čilea, ${ }^{61}$

56 Unatoč manjim razlikama, radi se o jedinstvenom pravnom sustavu utemeljenom na rimskoj pravnoj misli i inspiriranom francuskim i španjolskim građanskim zakonicima 19. stoljeća. Više Catalano, P., Diritto e persone I, Torino, G. Giappichelli Editore, 1990., str. 137.

57 V. bilj. 22.

58 Código Civil Boliviano, Gaceta No 800 del 15 de Agosto de 1975 (u daljnjem tekstu Građanski zakonik Bolivije), članak 1398.: La pignoración de bienes muebles se llama prenda; la de inmuebles, anticresis.

59 Građanski zakonik ove otočne države stupio je na snagu 1825. godine i u potpunosti je preslika Francuskog građanskog zakonika pa antihreza postoji kao vrsta nantissement ugovora, koji u slučaju zaloga pokretnina nosi naziv gage, a kada se odnosi na nekretnine onda se naziva antihreza. Alegre de Miguel, J. D., op. cit., str. 68.

60 Código Civil de la República Dominicana, Modificado por la Ley 1930 del 1949, članak 2072.:El empeño de una cosa mobiliaria se llama prenda. El de una cosa inmobiliaria se llama anticresis.

61 Codigo Civil de Chile, Decreto con Fuerza de Ley 1, 21-ABR-2015 Ley 20830, članak 2438.: (1) La anticresis no da al acreedor, por sí sola, ningún derecho real sobre la cosa entregada.(2) Se aplica al acreedor anticrético lo dispuesto a favor del arrendatario en el caso del artículo 1962. (3) No valdrá la anticresis en perjuicio de los derechos reales ni de los arrendamientos anteriormente constituidos sobre la finca. 
Ekvadora, ${ }^{62}$ Venezuele ${ }^{63}$ Urugvaja ${ }^{64}{ }^{6}$ Kolumbije ${ }^{65}$ i El Salvadora ${ }^{66}$ izričito propisuju da zaključenjem ugovora o antihrezi ne nastaje za vjerovnika nikakvo stvarno pravo na predmetu ugovora o antihrezi, koju smatraju institutom osiguranja tražbina. U svim zakonicima Latinske Amerike predmet antihreze isključivo je nekretnina, osim u Građanskom zakoniku Argentine koji izmjenama iz 2015. godine proširuje predmet ugovora o antihrezi dodajući uz plodonosne nekretnine i registrirane pokretnine. ${ }^{67}$

$\mathrm{U}$ istraživanju latinoameričke prakse na tržištu nekretnina svakako se ističe specifičan modalitet ugovaranja kompenzacijske antihreze kao svojevrsne alternative ugovoru o najmu nekretnine. Temeljna karakteristika režima, tzv. antihreznog najma je da jedna strana prenosi ovlaštenje korištenja nekretnine, za što druga strana pri zaključenju ugovora isplaćuje (jednokratno) ugovorenu cijenu (iznos novca), a koji se po isteku antihreznog najma u cijelosti vraća. Time jedna ugovorna strana dobiva povoljan kapital bez skupih bankovnih kredita, a druga privremeno rješava stambeno pitanje i istodobno štedi novac koji će dobiti nazad po isteku ugovora. ${ }^{68}$

Iz razloga procjene atraktivnosti mogućih rješenja, a ograničeni opsegom rada, u okviru latinoameričkih država izdvojit ćemo primjer bolivijskog iskustva s

62 Código Civil Ecuatoriano, Codificacion 010, Registro Oficil, Suplemento 46 De 24/06/ 2005, članak 2340.: (1) La anticresis no da al acreedor, por sí sola, ningún derecho real sobre la cosa entregada. (2) Se aplica al acreedor anticrético lo dispuesto a favor del arrendatario en el caso del Art. 1903. (3) No valdrá la anticresis en perjuicio de los derechos reales ni de los arrendamientos anteriormente constituidos sobre la finca.

63 Código Civil de Venezuela, Gaceta No 2.990 Extraordinaria del 26 de Julio de 1982, članak 1861.: La anticresis no concede ningún privilegio al acreedor. Este tiene solamente el derecho de retener el inmueble hasta que su acreencia sea totalmente pagada.

64 Código Civil de la República Oriental del Uruguay, 26 de febrero de 2010, članak 2352.: (1) El acreedor anticrético no adquiere derecho real sobre la cosa ni vale la anticresis contra los derechos reales ni enperjuicio de los arrendamientos constituidos anteriormente en la finca. (2) Pero serán obligados a respetar el derecho del acreedor anticrético, todos aquellos a quienes se transfiera el derecho del dueño de la cosa con posterioridad a la constitución de la anticresis, siempre que ésta se haya inscrito en el Registro correspondiente.

65 Codigo Civil Colombiano, Ley 57 de 1887, članak 2461.: (1) La anticresis no da al acreedor, por si sola, ningún derecho real sobre la cosa entregada.(2) Se aplica al acreedor anticrético lo dispuesto a favor del arrendatario, en el caso del artículo 2020. (3)No valdrá la anticresis en perjuicio de los derechos reales, ni de los arrendamientos anteriormente constituidos sobre la finca.

66 Código Civil de la República de El Salvador, Gaceta Oficial de 19 de mayo de 1860, članak 2184.: La anticresis no da al acreedor, por sí sola, ningún derecho real sobre la cosa entregada. Se aplica al acreedor anticrético lo dispuesto a favor del arrendatario en el caso del artículo 1750, si el contrato de anticresis hubiese sido inscrito.No valdrá la anticresis en perjuicio de los derechos reales ni de los arrendamientos anteriormente constituidos sobre la finca.

67 Opisana izmjena zapravo je vrlo logična s obzirom na to da se na registrirane pokretnine $u$ pravilu primjenjuju ista pravila kao i za nekretnine kada je u pitanju stjecanje i prijenos stvarnih prava, kao i zasnivanje prava osiguranja tražbina.

68 S ekonomskog gledišta lako je pronaći opravdanje za postojanje ovakvog instituta u zemljama s vrlo visokim stopama inflacije, ali nešto je teže zamisliti da kamata na određeni iznos kapitala (koji očito nikada neće biti jednak vrijednosti nekretnine jer bi u protivnome bila odmah kupljena) može kompenzirati zaradu koja bi se ostvarila ugovorom o najmu. Čini se da je to moguće jedino ako je kamatna stopa, kao posljedica inflacije, vrlo visoka. 
primjenom antihreznog najma, s obzirom na to da je upravo u praksi ove države taj institut pronašao svoju praktičnu primjenu koja bi mogla poslužiti kao inspiracija mogućnosti uređenja antihreze $\mathrm{u}$ hrvatskom pravnom poretku. ${ }^{69}$

Bolivijsko pravo (članak 1398. Građanskog zakonika Bolivije, cit. bilj. 59) zalog nepokretne stvari naziva antihreza (anticresis). Ovo pravo nastaje na temelju ugovora o antihrezi koji može biti amortizacijske ili kompenzacijske prirode, odnosno može vjerovnika ovlastiti na ubiranje plodova stvari kako bi njima namirio prvo kamate, a zatim i glavnicu svog potraživanja ${ }^{70}$ ili može ovlastiti vjerovnika da sve prihode nekretnine kompenzira s kamatama. ${ }^{71}$ Jednako kao i u talijanskom pravu, prema bolivijskim propisima ugovor o antihrezi treba biti zaključen u obliku javne isprave, ${ }^{72}$ a predmetom ugovora mogu biti isključivo nekretnine. Ugovaranjem antihreze nastaje stvarno pravo antihreze koje je nedjeljivo, a prema trećim osobama ostvaruje učinke tek nakon upisa u registar nekretnina. ${ }^{73}$ Moguće je ugovoriti antihrezu na razdoblje od maksimalno pet godina. ${ }^{74}$

69 Antihrezni najam pojavljuje se u mnogim zemljama civilnog sustava prava. Podrazumijeva paušalno plaćanje određenog iznosa od strane najmoprimca, a taj se iznos u cijelosti vraća na kraju isteka najma, pri čemu je zadržavanje tog paušalnog iznosa od strane vlasnika nekretnine, njegova kompenzacija za najam iste. Primjerice, najmoprimac plati najmodavcu 13.000 USD na početku ugovora o najmu i najmodavac mu istekom ugovora vrati 13.000 USD. Najmodavčeva efektivna zarada tijekom perioda antihreznog najma nekretnine je kamata koju može ostvariti oroči li taj iznos, koja doseže otprilike 108 USD mjesečno ili investicijska zarada koju može ostvariti s tom svotom novca. Suprotno tomu, prosječna mjesečna najamnina plaćena od najmoprimca najmodavcu pod klasičnim ugovorom o najmu iznosi oko 150 USD. Više Navarro, I., Turnbull, G. K., Antichresis leases: Theory and empirical evidence from the Bolivian experience, Regional Science and Urban Economics, vol. 40, 1/2010, str. 33; Espinoza, F. F., Bolivia's Land Tenure Experience, chapter ten, u: Land, Rights \& Innovation, Improving Tenure Security for the Urban Poor, (ur.) Payne,G., London, ITDG Publishing, 2002., str.185. Nekoliko je uzgrednih objašnjenja zašto se nastavljaju koristiti antihrezni najmovi. Jedno od popularnih je to da su antihrezni najmovi motivirani visokom inflacijom ili velikim rastom kamata na zajmove pa su stanodavci prisiljeni financirati svoje projekte kroz antihrezu. Ostala opravdanja za antihrezu temeljena su na lokalnim institucionalnim faktorima. Primjerice, jedan je argument da porezi i pristojbe na ugovor o najmu stvaraju prednosti/nedostatke za antihrezu ovisno o različitim vrstama nekretnina i najmoprimaca. Navarro, I., op. cit., str. 35-36.

70 Građanski zakonik Bolivije, članak 1429., I.: Por el contrato de anticresis el acreedor tiene derecho a percibir los frutos del inmueble, imputándolos primero a los intereses, si son debidos, $y$ después al capital.

71 Građanski zakonik Bolivije, članak 1429., II.: Es válido el pacto por el cual las partes convienen en que los frutos se compensen con los intereses en todo o en parte.

72 Građanski zakonik Bolivije, članak 491.: Deben celebrarse por documento público 1) El contrato de donación, excepto la donación manual. 2) La hipoteca voluntaria. 3) La anticresis. 4) La subrogación consentida por el deudor. 5) Los demás actos señalados por la ley. O potrebi zaključenja ugovora o antihrezi u obliku javne isprave govori i presuda bolivijskog suda Sala Civil Segunda de la Corte Superior del Distrito Judicial de Oruro, 154/2011, od 20. travnja 2011.

73 Građanski zakonik Bolivije, članak 1430.: El contrato de anticresis no se constituye sino por documento público, y surte efecto respecto a terceros sólo desde el día de su inscripción en el registro. U prilog tomu govori i sudska praksa Sala Civil Primera de la Corte Superior del Distrito Judicial de Santa Cruz, 41/2006, od 15. ožujka 2006.

74 Građanski zakonik Bolivije, članak 1435.: II. La anticresis no puede convenirse por un plazo 
Antihrezni vjerovnik ima pravo ius retentionis, ${ }^{75} \mathrm{kao}$ i ius distrahendi uz pravo prvenstva u namirenju s obzirom na vjerovnike čija su prava nastala nakon upisa prava antihreznog vjerovnika u zemljišne knjige (ius praelationis). ${ }^{76}$ Dužan je plaćati godišnje poreze i troškove nekretnine te se brinuti o nekretnini i upravljati njome pažnjom dobroga gospodarstvenika. Troškove koje snosi vršenjem ovih obveza može namiriti iz plodova nekretnine. Ako se želi osloboditi opisanih obveza, može u bilo kojem trenutku vratiti nekretninu antihreznom dužniku, ako nije drukčije ugovoreno. ${ }^{77}$

Jedan od osjetnijih bolivijskih problema je vlasništvo nekretnina, posebice uzevši u obzir da se zemlja ili kuća najčešće koriste kao zalog za različite zajmove. ${ }^{78}$ Upravo stoga je u Boliviji uporaba kompenzacijske antihreze (ili antihreznog najma) raširena za stambene namjene. ${ }^{79}$ Statistički podatci iz 2002. godine pokazuju da je antihreza treći najkorišteniji tip najamnog ugovora u Boliviji. ${ }^{80}$ Prema bolivijskoj praksi, antihrezni najam realizira se kao ugovor o antihrezi između stanodavca $\mathrm{i}$ stanoprimca koji bi inače zaključili klasični ugovor o najmu. Na osnovi zaključenog antihreznog ugovora stanodavac prima određeni iznos novca, a stanoprimac stječe pravo koristiti nekretninu u dogovorenom roku. Riječ je o razmjeni uživanja koje pruža korist za obje strane. Stanodavac daje na korištenje nekretninu stanoprimcu i za to se naplaćuje ubiranjem plodova kapitala koji dobiva u zajam. S druge strane, stanoprimac daje stanodavcu određeni iznos kapitala, ali cijenu pozajmljivanja tog kapitala naplaćuje ubiranjem plodova nekretnine stanovanjem u njoj. ${ }^{81}$

superior a cinco años y si se pacta otro mayor, él se reduce a dicho término.

75 Građanski zakonik Bolivije, članak 1435.: III. El anticresista tiene el derecho de retención mientras no sea satisfecho su crédito, salvo lo dispuesto por el artículo 1479.

76 Građanski zakonik Bolivije, članak 1432.: El acreedor anticresista tiene el derecho de hacerse pagar con preferencia a otros acreedores sobre la cosa recibida en anticresis. (Art. 1337 del Código Civil).

77 Građanski zakonik Bolivije, članak 1434.: I. El acreedor, si no se ha acordado otra cosa está obligado a pagar los impuestos y las cargas anuales del inmueble. II.Tiene la obligación de conservar, administrar y cultivar el fundo como un buen padre de familia. Los gastos correspondientes se deben sacar de los frutos. III. El acreedor, si quiere liberarse de esas obligaciones, puede en todo momento restituir el inmueble al constituyente, siempre que no haya renunciado a tal facultad.

78 Više Espinoza, F. F., op. cit., str.182-183.

79 Od 1992. do 2001. godine u deset najvećih bolivijskih gradova porasla je uporaba antihreznog najma. Opće je mišljenje da je tako popularna zbog bolivijskoga traumatičnog iskustva $s$ visokom inflacijom i jer visoke kamatne stope prisiljavaju vlasnike nekretnina financirati svoje projekte iz antihreznih ugovora. Navarro, I., op. cit., str. 148. V. dalje bilj. 83.

80 Espinoza smatra da je u praksi, ovaj postotak i veći, jer se službeni izvori odnose samo na one ugovore koji su zaključeni sukladno zakonskoj proceduri (ovjera i registracija ugovora), što se u mnogo slučajeva ne provodi. Espinoza, F. F., op. cit., str. 184.

81 Ovakav dogovor uključuje i nekoliko različitih odgovornosti jedne i druge strane koje se temelje na zakonskim odredbama o antihrezi i nekim dodatnim uglavcima koji predstavljaju dispoziciju stranaka. Tako se, primjerice, često ugovara mogućnost da antihrezni dužnik kupi nekretninu koju koristi na temelju zaključene antihreze, nakon što istekne ugovoreni period. U pravilu se ovaj scenarij realizira kada je riječ o nekretninama koje su pod antihrezom duže razdoblje, od četiri do osam godina. Također, ova je opcija moguća i u slučajevima kada vlasnik nekretnine nije u mogućnosti vratiti ugovoreni iznos novca po dospijeću njegove obveze da to učini. Espinoza, F. F., op. cit., str. 185. 
Takav antihrezni sustav može biti vrlo učinkovit način iskorištavanja nekretnina koje u protivnome stoje prazne i bez svrhe, a istodobno je i način dolaska do jeftinog kapitala te stoga može poboljšati životne uvjete i omogućiti srednjoj klasi uštedu za kupnju svoje prve nekretnine ili, čak, nakon određenog vremena, kupnju nekretnine koja je bila predmetom ugovora o antihrezi. ${ }^{82} \mathrm{U}$ bolivijskoj praksi prepreku maksimalnom iskorištavanju potencijala ovog instituta čine pretjerana birokratizacija i visoki porezi, stvarajući kontraučinak i tako nanoseći štetu gospodarstvu umjesto isticanja perspektive i važnosti provedbe antihreze kao sredstva poboljšanja životnih uvjeta, smanjenja siromaštva i razvijanja ekonomije. ${ }^{83}$

\section{UMJESTO ZAKLJUČKA - ANTIHREZA U HRVATSKOM ZAKONODAVSTVU DE LEGE FERENDA}

Iako je hrvatska pravna tradicija utemeljena na rimskom pravnom sustavu ${ }^{84} \mathrm{i}$ unatoč tomu što su neki srednjovjekovni hrvatski statuti poznavali institut pactum

82 Jedan od načina rješavanja pitanja stanovanja prepoznat je u ugovoru o antihrezi. Budući da stanar cijeli iznos plaća vlasniku na samom početku, on nema rizika da će stanar postati nelikvidan. Kao rezultat toga, iznos antihreze će biti niži nego kod klasičnog najma, što je karakteristika koja čini antihrezu privlačnim sredstvom za stanovanje siromašnih (usp. bilj. 80). S druge strane, antihrezni mehanizam može biti nedostižan najsiromašnijoj populaciji koja nema pristup većoj svoti novca koja je potrebna kako bi ušli u taj ugovorni odnos. Oni stanari koji imaju veći iznos novca ujedno su i oni za koje je manja mogućnost da će postati nelikvidni tijekom trajanja ugovora. Oni koji si ne mogu priuštiti ovaj ugovor, imaju samo opciju klasičnog najma s višim najamninama. Politika koja čini evikcije sve skupljima i na druge načine čini klasični najam manje profitabilnim, dovodi vlasnike šireg kruga nekretnina prema antihrezi, još više sužavajući mogućnosti za najsiromašnije. Navarro, I., op. cit., str. 134. Slično se koristi se u Koreji ugovor chonsei koji predstavlja antihrezni najam i omogućuje rješavanje brojnih problema stanovanja. V. više Kim, J., Financial Repression and Housing Investment: An Analysis of the Korean Chonsei, Journal of Housing Economics, vol. 22, 4/2013, str. 338-358; Ambrose, B. W., Kim, S., Modeling the Korean Chonsei Lease Contract, Real Estate Economics, vol. 31/2003, str. 53-74.

83 Potaknuta velikom primjenom antihreznog najma u praksi, bolivijska vlada je odlučila izraditi zakonski okvir za institut antihreze kako bi se povećala sigurnost obiju stranaka, što je dovelo do birokratiziranog postupka opterećenog povišenim porezima i taksama. Konačan rezultat je da se ugovori o antihreznom najmu zaključuju, ali bez njihove registracije u registru nekretnina, što ujedno onemogućuje ostvarenje bankarskih kredita u tu svrhu jer sve banke kao uvjet kreditiranja antihreznih najmova postavljaju registraciju ugovora i stvarnog prava antihreze. Espinoza, F. F., op. cit., str. 190-192.

84 U materiji hrvatskoga založnog prava jasno su vidljivi rimski temelji, ponajprije u konceptu instituta stvarnopravnih osiguranja tražbina, ručnog zaloga i hipoteke. Sukladno Ulpijanovu stajalištu ova dva instituta razlikovala su se s obzirom na činjenicu posjedovanja založene stvari. Tek Hugo Grotius u 17. stoljeću uvodi i razlikovanje prema predmetu osiguranja, pa tako predmetom osiguranja ručnim zalogom mogu biti samo pokretne stvari, dok hipoteka može postojati samo na nekretninama. Ovaj kriterij razlikovanja slijedio je austrijski Opći građanski zakonik, kao i jugoslavenski propisi, dok je hrvatski Zakon o vlasništvu i drugim stvarnim pravima iznova aktualizirao Ulpijanov kriterij posjedovanja. Petrak, M., Rimska pravna tradicija i hrvatsko stvarno pravo, Zbornik Pravnog fakulteta u Zagrebu, vol. 52, 5/2002, str. 122. 
antichreticum ${ }^{85}$ za suvremeno hrvatsko pravo ključan je bio utjecaj austrijskog i njemačkog prava, čijem pravnom krugu Hrvatska i pripada. Zakon o vlasništvu i drugim stvarnim pravima ${ }^{86}$ slijedi Austrijski građanski zakonik ${ }^{87}$ prema kojem hipotekarni vjerovnici i vjerovnici čije su tražbine osigurane nedobrovoljnim ili zakonskim založnim pravom na pokretninama te registarskim založnim pravima, nemaju pravo na posjed zaloga, niti su ovlašteni ubirati i prisvajati plodove i koristi od zaloga te i općenito upotrebljavati zalog. ${ }^{88}$

ZV zabranjuje da se hipotekarnom vjerovniku dopusti posjedovanje i upotrebljavanje nekretnine koja je pod hipotekom, propisujući člankom 329. kako hipotekarni vjerovnik nema pravo na posjed založene nekretnine, niti ima pravo ubirati i prisvajati njezine plodove i druge koristi ili bilo kako upotrebljavati tu nekretninu. U stavku 2. istog članka propisuje kako je odredba ugovora ili drugoga pravnog posla suprotna stavku 1. članka 329., ništetna. Iz navedenoga članka razvidno je kako hrvatsko pravo zabranjuje pactum antichreticum uz hipoteku, a ne poznaje ugovor o antihrezi u smislu amortizacijske i/ili kompenzacijske antihreze. ${ }^{89}$

Antihrezu kontinuirano kritiziraju i ekonomski i pravni stručnjaci. Kritički

85 Za razliku od statuta istarske pravne regije, u slavonskim, hrvatskim i dalmatinskim, postoje odredbe koje ukazuju na to da je nekretnina davana na plodouživanje vjerovniku u zamjenu za kamate, dok dužnik ne vrati dug. Zanimljivo je usporediti zabranu Umaškog, Pulskog, Rovinjskog statuta s odredbama Splitskog i Zadarskog statuta koji su dopuštali takva ugovaranja. Kako Margetić navodi, sukladno odredbama Splitskog statuta glavna je karakteristika zaloga vjerovnikovo pravo da zadrži založenu stvar i uživa njezine plodove sve dok dužnik ne vrati zajam zbog kojeg je dano osiguranje u vidu zaloga. Ovakav tip zaloga požuruje dužnika da vrati dugovano, kako bi čim prije dobio nazad posjed založene stvari. V. detaljnije Margetić, L., Diritto medievale croato, Diritti reali, Atti del Centro di Ricerche Storiche Rovigno, vol. 14/1983/84, str. 98.

86 Zakon o vlasništvu i drugim stvarnim pravima Republike Hrvatske, Narodne novine, br. 91/96, 68/98, 137/99, 22/09, 73/00, 114/01, 79/06, 141/06, 146/08, 38/09, 153/09, 143/12 (u daljnjem tekstu ZV).

87 Austrijski građanski zakonik (Allgemeines bürgerliches Gesetzbuch), JGS Nr. 946/1811.

88 Mihelčić, G., op. cit., str. 317.

89 Iako je antihrezni sporazum zabranjen uz hipoteku, prema Kunšteku bi se učinak takvog sporazuma mogao postići ekstenzivnim tumačenjem članka 331. ZV-a, koji propisuje kako založni vjerovnik ima pravo ubirati civilne plodove nekretnine koju posjeduje na temelju nekog pravnog odnosa, ako mu je založeno samo pravo na plodove. „Istina je da antikrezu prilično često koriste ljudi sumnjiva morala ili pripadnici kriminalnog podzemlja - no zlouporaba jednog pravnog instituta ne bi trebala predstavljati razlog za njegovu apsolutnu zabranu. Onda bi cijela pravnofilozofska konstrukcija 'zabrane zlouporabe prava' postala besmislena. Uostalom, ne postoji niti jedno pravo koje se ne može zlorabiti. Kada je u pitanju antikreza, moguće su različite koristi od njenog dopuštanja i masovnije primjene. One su u svakom slučaju daleko veće od eventualnih negativnih posljedica. Naime, u nizu država antikreza u stvarnosti predstavlja značajan instrument za rješavanje stambenih problema osoba koje nemaju dovoljno sredstava za kupnju nekretnine. Dakako, s druge strane ona omogućuje vlasnicima nekretnina, u pravilu građevinskim poduzetnicima, da bez prijenosa prava vlasništva ipak dođu do dijela sredstava potrebnih za nastavak njihove djelatnosti. Prema tome, antikreza može imati važan gospodarski i opći društveni značaj.“ Kunštek, E., Prijenos prava vlasništva radi osiguranja tražbina prema novelama Ovršnog zakona 2003., Zbornik Pravnog fakulteta Sveučilišta u Rijeci, vol. 25, 1/2004, str. 374. 
osvrti u pravilu polaze od teze da ona smanjuje produktivnost nekretnine ili njezin prihod, jer umanjuje vjerovnikov interes ulaganja kapitala u održavanje nekretnine. Osim toga, kvalificira se preprekom kreditima budući da sprječava davanje nekretnine u cilju osiguranja drugih obveza, stvarajući ograničenje na cijeloj nekretnini, neproporcionalno s potrebama obveze koja se ima ispuniti. U komparaciji antihreze s hipotekom, potonja se uvijek procjenjuje pobjednicom jer se (površno gledajući) hipoteka čini povoljnijim pravnim institutom. Razlog tomu je što se kauzom antihreze smatra isključivo osiguranje tražbine, a zanemaruje se da antihrezni vjerovnik, osim osiguranja koje mu pruža posjedovanje nekretnine, ima i veoma učinkovito sredstvo namirenja svoje tražbine jer se trenutkom zaključenja ugovora pokreće mehanizam koji mu omogućuje namirenje iz plodova nekretnine, a upravo tu značajku treba iskoristiti kao prednost ovoga instituta.

S obzirom na to da je svrha ovoga rada bila istražiti postoji li razlog zašto bi se i na koji način trebalo promijeniti uređenje antihreze (u širem smislu) de lege lata u hrvatskom pravu, mišljenja smo da na osnovi iznesene povijesno pravne $\mathrm{i}$ komparativne analize instituta pactum antichreticum i antihreze, kao i na temelju općepoznatog pravnog, društvenog i socijalnog stanja u Hrvatskoj, možemo zaključiti kako bi reguliranje kompenzacijske i amortizacijske antihreze moglo ostvariti pozitivne učinke.

Iako je najistaknutiji primjer dobre prakse uporabe antihreze, onaj iz Bolivije, (i)realnost mogućnosti preuzimanja takvog modela pravnog uređenja povezana je s različitim dimenzijama ovog izazova. S obzirom na to da hrvatski pravni sustav poznaje numerus clausus stvarnih prava, što čini jedan od njegovih temelja, veoma je teško zamisliti da bi zakonodavac pravo koje nastaje na temelju ugovora o antihrezi regulirao kao stvarno pravo antihreze. Uostalom, kada bi antihreza bila stvarno pravo na tuđoj stvari koje uključuje ius possidendi, ius fruendi, ius distrahendi te ius prelationis, hipoteka bi doista bila privlačniji institut, omogućavajući dužniku zadržavanje posjeda nekretnine. Upravo zato valjalo bi razmišljati u drugome smjeru i razmotriti mogućnost reguliranja ugovora o antihrezi kao instrumenta dobrovoljnog anticipiranog namirenja i osiguranja tražbine, ali koje ne podrazumijeva i ius distrahendi te ius prelationis. Kako bi se ugovornim strankama pružila bolja zaštita i svim sudionicama u pravnom prometu dala veća pravna sigurnost, ovaj bi ugovor trebalo zabilježiti u zemljišnim knjigama s učinkom erga omnes, po uzoru na talijansko pravo.

Kompenzacijska antihreza, to jest antihrezni najam, mogao bi doprinijeti rješavanju stambenog pitanja mladih i pružanju alternativnih sredstava financiranja koji su povoljniji od skupih zajmova. S obzirom na to da je stambeno pitanje mladih usko povezano s pitanjem povoljnih izvora financiranja, učinkovito i alternativno rješenje moglo bi se postići antihreznim najmom, odnosno kompenzacijskom antihrezom po uzoru na bolivijsku praksu, no razumljivo, uz potrebne modifikacije. Reguliranje antihreze, sukladno bolivijskom primjeru, ali koje svakako mora biti oslobođeno suvišne birokratizacije i skupih nameta, a opet dovoljno osigurano javnobilježničkim aktom kako bi stranke maksimalno umanjile rizik, omogućilo bi jednostavnije rješavanje stambenog pitanja mladih i pristup kapitalu, i jedno i drugo 
po uvjetima povoljnijim nego na tržištu najma nekretnina i bankovnih kredita.

Nadalje, amortizacijska antihreza kao sredstvo namirenja i osiguranja tražbine olakšala bi pristup kreditima u situaciji sloma kreditnog tržišta, jer bi se osim vrijednosti nekretnine (na temelju hipoteke) mogla ponuditi i vrijednost uporabe te nekretnine, a zajmodavca ujedno staviti u povoljniji položaj u kojem svoju tražbinu može namirivati postupno i prije dospijeća, a ne samo nakon zakašnjenja dužnika. Najveća vrijednost amortizacijske antihreze upravo je u tomu što se režimom ovog ugovora od dvije moguće vrijednosti nekretnine (vrijednost uporabe i prodajna vrijednost) kompromitira samo jedna, a to je vrijednost uporabe, dok vlasnik i dalje za sebe zadržava prodajnu vrijednost te ne ugrožava svoje vlasništvo, pa s njime može raspolagati u skladu sa svojim potrebama i željama.

Konačno, institut amortizacijske antihreze pomogao bi u rješavanju problema građevinskog sektora u kojem se obujam radova drastično umanjio što usporedno prati i smanjivanje broja radnih mjesta, a kao tekući problem pojavljuje se i vraćanje skupih zajmova koje su te iste tvrtke ugovorile kako bi uopće izgradile građevinu koju sada/potom ne mogu prodati. Umjesto da banke naplatu pokušavaju realizirati ovrhom nad tim nekretninama (uspjeh čega je također vrlo upitan), stvorila bi se mogućnost aktiviranja njihove vrijednosti ugovorima o antihrezi kojima bi se riješilo pitanje njihova namirenja te koordiniralo pitanje kapitala kvalitetnim omjerima za investicije i novim izvorima podrške rada građevinskim tvrtkama.

$\mathrm{Na}$ ovaj način, uvođenjem instituta ugovora o antihrezi u hrvatski pravni poredak moglo bi se utjecati na pomake utri osjetljiva područja, iako bi učinkovitost ovog instituta ponajviše ovisila o porezima i pristojbama koji će se propisati u svezi sa zaključenjem ovih ugovora, pri čemu treba kontinuirano osigurati da birokratizacija i pretjerani nameti ne unište svrhu instituta koji trebaju biti povoljni i jednostavni.

\section{LITERATURA}

Vrela:

1. Corpus iuris civilis: Vol. I. Institutiones (recognovit P. Krueger); Digesta (recognovit T. Mommsen, retractavit P. Krueger); Vol. II. Codex Iustinianus (recognovit et retractavit Krueger); Vol. III. Novellae (recognovit R. Schoell, opus Schoellii morte interceptum absolvit G. Kroll); Dublin-Zürich (Weidmann), 1973. (Vol. I.).; 1967. (Vol. II.), 1972. (Vol. III.)

2. Gordon, William M., Robinson, Olivia F. (eds.), The Institutes of Gaius, Cornell (UP), 1988.

3. Mommsen, Theodor, Krüger, Paul, Watson, Alan, (eds.), The Digest of Justinian, (vol. I.-IV.), Pennsylvania, 1985.

4. Mommsen, Theodor, Meyer, Paul, (eds.), Theodosiani libri XVI. cum consuetudinibus Sirmondianis et Leges ad Theodosianum pertinentes, Berolini, 1905.

5. Pothier, Robert G., Le Pandette di Giustiniano, Vol. I; Venezia, Co'tipi di Antonio Bazzarini, 1833.

6. Pothier, Robert G., Le Pandette di Giustiniano, Vol. II; Venezia, Co'tipi di Antonio Bazzarini, 1841.

7. Scott, Samuel P., The Civil Law, IV; The Enactments of Justinian.The Digest Or Pandects, Book XIII, Cincinnati, 1932.

8. Voet, Giovanni, Commento alle Pandette, Venezia, Co’tipi di Antonio Bazzarini, 1837. 
Zakonski tekstovi:

1. Austrijski građanski zakonik (Allgemeines bürgerliches Gesetzbuch), JGS Nr. 946/1811.

2. Code civil des Français, French Civil Code, as of 1st July 2013 (Translation: David W. Gruning, Professor Of Law, Loyola University, School of Law, New Orleans).

3. Código Civil Boliviano, Gaceta No 800 del 15 de Agosto de 1975.

4. Codigo Civil de Chile, Decreto con Fuerza de Ley 1, 21-ABR-2015 Ley 20830.

5. Código Civil de la República de El Salvador, Gaceta Oficial de 19 de mayo de 1860.

6. Código Civil de la República Dominicana, Modificado por la Ley 1930 del 1949.

7. Código Civil de la República Oriental del Uruguay, 26 de febrero de 2010.

8. Código Civil de Venezuela, Gaceta N 2.990 Extraordinaria del 26 de Julio de 1982.

9. Codigo Civil Colombiano, Ley 57 de 1887.

10. Código Civil Ecuatoriano, Codificacion 010, Registro Oficil, Suplemento 46 De 24/06/ 2005.

11. Código Civil Español, 25 de julio de 1889, última modificación: 6 de octubre de 2015.

12. Il Codice Civile Italiano, Gazzetta Ufficiale, $n$. 79 del 4 aprile 1942, ultimo aggiornamento: marzo 2000.

13. Zakon o vlasništvu i drugim stvarnim pravima Republike Hrvatske, Narodne novine, br. 91/96, 68/98, 137/99, 22/09, 73/00, 114/01, 79/06, 141/06, 146/08, 38/09, 153/09, 143/12.

Knjige i članci:

1. Alegre de Miguel, Jorge D., La anticresis: funcion e finalidad en el Codigo Civil espanol $y$ en el Codigo Civil de Cataluna, Barcelona, ESADE, Facultat de Derecho, Universitat Ramon Llull, 2013.

2. Ambrose, Brent W., Kim, Sunwoong, Modeling the Korean Chonsei Lease Contract, Real Estate Economics, vol. 31/2003, str. 53-74.

3. Anić, Šime, Klaić, Nikola, Domović, Želimir, Rječnik stranih riječi, Tuđice, posuđenice, izrazi, kratice i fraze, Zagreb, SANI-PLUS, 2002.

4. Bobbink, Rian, Antichresis: het vergeten zekerheidsrecht, Een historische vergelijking met het Franse recht, GROM 2016, on line publication, preuzeto s file://D:/Users/Ines/ Downloads/28933-34063-1-SM\%20(2).pdf, 8. siječnja 2019.

5. Camonita, Salvatore, L'anticresi e la garanzia del credito, preuzeto s www.diritto.it, objavljeno 23.02.2012.

6. Catalano, Pierangelo, Diritto e persone I, Torino, G. Giappichelli Editore, 1990.

7. Cicero, Cristiano, Il Codice Civile, Commentario, Giuffre Editore, Milano, 2010.

8. Cohen, Boaz, Antichresis in Jewish and Roman Law, New York, Shulsinger Bros. Inc., 1966.

9. Eichler, Barry. L., Indenture at Nuzi, The Personal Tidennūtu Contract and its Mesopotamian Analogues, London, Yale University Press, 1973.

10. Ellickson, Robert C., Thorland, Charles, Ancient Land Law: Mesopotamia, Egypt, Israel, Chicago-Kent Law Review, vol. 71/1995, str. 394-399.

11. Espinoza, Fabian Farfan, Bolivia's Land Tenure Experience, chapter ten, u: Land, Rights \& Innovation, Improving Tenure Security for the Urban Poor, (ur.) Payne, G., London, ITDG Publishing, 2002.

12. Fragali, Michele, Commentario del Codice civile, Libro quarto, Delle obbligazioni, art. 1960 - 1991, Bologna, Nicola Zanichelli, 1974.

13. Giuffrè, Romilda, Di taluni contratti trascurati: il mandato di credito e l'anticresi, Corriere giuridico, 1/2012, str. 34-39.

14. Hernandez-Moreno, Alfonso, Antichresis o Contrarium Mutuum, Barcelona, Real Academia de Ciencias Economicas e Financieras, 2014.

15. Kim, Jinwon, Financial Repression and Housing Investment: An Analysis of the Korean Chonsei, Journal of Housing Economics, vol. 22, 4/2013, str. 338-358. 
16. Kunštek, Eduard, Prijenos prava vlasništva radi siguranja tražbina prema novelama Ovršnog zakona 2003., Zbornik Pravnog fakulteta Sveučilišta u Rijeci, vol. 25, 1/2004, str. 365-381.

17. Lachner, Višnja, Roškar, Jelena, Građanske kodifikacije u Europi s posebnim osvrtom na 19. i 20. stoljeće, Zbornik radova znanstvenog skupa "Austrijski građanski zakonik (1811-2011) “, Tuzla: Pravni fakultet Univerziteta u Tuzli i Pravni fakultet Sveučilišta J.J. Strossmayera u Osijeku, 2013., str. 31-49.

18. Lovera, Marco, El contrato de anticresis, Caracas, Universidad Católica Andrès Bello, 1993.

19. Macario, Francesco, Dei singoli contratti (art. 1861 - 1986), Torino, Utet Giuridica, 2009.

20. Manigk, Alfred, Bullettino dell 'istituto di Diritto Romano, Roma, Facoltá Giuridica della Roma Universitá, 1911.

21. Margetić, Lujo, Diritto medievale croato, Diritti reali,Atti del Centro di Ricerche Storiche Rovigno, vol. 14/1983/84, str. 77-161.

22. Mastropaolo Fulvio, L'anticresi come contratto costitutivo di garanzia consistente in poteri su cose immobili, Rivista di diritto civile, vol. 50, 5/2004, str. 707-747.

23. Matić, Ines, Pactum antichreticum, doktorska disertacija, Rijeka, Pravni fakultet u Rijeci, 2017.

24. Matić, Ines, Petranović, Anamari, Antihreza u rimskoj pravnoj doktrini, Zbornik Pravnog fakulteta Sveučilišta u Rijeci, vol. 39, 3/2018, str. 1153-1168.

25. Mecenate, Fulvio, L'anticresi, Una possibile alternativa per il mercato immobiliare e per l'accesso al credito, Gazzetta Notarile, 7/9/2014

26. Mihelčić, Gabrijela, Izvansudsko namirenje stvarnopravno osiguranih tražbina, doktorska disertacija, Zagreb, Pravni fakultet Sveučilišta u Zagrebu, 2011.

27. Mirabelli, Giuseppe, Dell'anticresi, Napoli, Editore Federico Corrado, 1888.

28. Mousourakis, George, Roman Law and the Origins of the Civil Law Tradition, London, Springer, 2015.

29. Murillo, Maria Luisa, The evolution of Codification in the Civil Law Legal Systems: Towards Decodification and Recodification, Journal of Transnational Law\&Policy, vol. 11, 1/2001, str. 1-20.

30. Navarro, Ignacio, Housing tenure, property rights and urban development in developing countries, Georgia Institute of Tehnology and Georgia State University, 2008.

31. Navarro, Ignacio, Turnbull, Geoffrey K., Antichresis leases: Theory and empirical evidence from the Bolivian experience, Regional Science and Urban Economics, vol. 40, 1/2010, str. 33-44.

32. Nicita, Francesco Paolo, Giurisprudenza sistematica civile e commerciale, Anticresi, Unione tipografico - Editrice Torinese, 1968.

33. Openheim, Leonard, Antichresis: an ancient security device revived (Editorial-Comments, T. L. R. 1938), Tulane Law Review, vol. 13/1938, str. 131-143.

34. Persico, Giovanni, Anticresi, u: Enciclopedia del Diritto, vol. II, Milano, Giuffre Editore, 1958.

35. Petrak, Marko, Rimska pravna tradicija i hrvatsko stvarno pravo, Zbornik Pravnog fakulteta u Zagrebu, vol. 52, 5/2002, str. 1045-1060.

36. 36. Purves Pierre M., Commentary on Nuzi Real Property in the Light of Recent Studies, Journal of Near Eastern Studies, vol. 4, 2/1945, str. 68-86.

37. Purves Pierre M., Additional Remarks on Nuzi Real Property, Journal of Near Eastern Studies, vol. 6, 3/1947, str. 181-185.

38. Ratto, Leonardo, I contratti agrari e di lavoro nel codice di Hammurabi, Rivista Internazionale di Scienze Sociali e Discipline Ausiliarie, vol. 35, 138/1904, str. 219-222.

39. Romac, Ante, Rječnik rimskog prava, Zagreb, Informator, 1975.

40. Speiser, Ephraim Avigdor, New Kirkuk Documents Relating to Security Transactions, Journal of the American Oriental Society, vol. 52, 4/1932, str. 350-367. 
41. Tedeschi, Vittorio, L'Anticresi, Torino, Unione Tipografico - Editrice Torinese, 1952.

42. Thomas, Philip, Antichresis, Hemiolia and the Statutory Limit on Interest in Gerard Noodt's De foenore et usuris, De Jure, vol. 40, 1/2007, str. 52-68.

43. Van Niekerk, S. J., et al. (ur.), The Three Book on Interest - bearing Loans and Interest (Foenus et Usurae) by Gerard Noodt, Leiden, Pretoria University Law Press, 2009.

44. Wells, Bruce, The Quasi-Alien in Leviticus 25. The Foreigner and the Law: Perspectives from the Hebrew Bible and the Ancient Near East, Beihefte zur Zeitschrift für altorientalische und biblische Rechtsgeschichte; Bd. 16. Wiesbaden, Germany: Harrassowitz Verlag, 2011.

45. Zimmermann, R., The New German Law of Obligations, Historical and Comparative Perspectives, New York, Oxford University Press, 2005. 


\title{
Ines Matić* \\ Anamari Petranović**
}

\author{
Summary
}

\begin{abstract}
ANTICHRESIS DE LEGE FERENDA
The Croatian Act on Ownership and Other Real Rights, Article 329 (paragraph 1) prohibits a mortgage lender from possessing and using the immovable property that is the subject of a mortgage, including the collection of fruits or other benefits from referring subject, further prescribing (paragraph 2) as null and void provision of opposite contractual order. Consequently, by this provision Croatian legislative platform does prohibit pactum antichreticum, while antichresis, as an independent contract, is not (co)existant. The aim of this paper is to examine the potential advantages in regulation of the institute of antichresis and / or pactum antichreticum that is considering Croatian law de lege ferenda. For this purpose, the first part of the paper provides the functionally summarized historical legal analysis of these institutes that propedeutically support the comparative analysis of their position in contemporary law, which has been examined in the second part of the paper, leading to their conclusive evaluation and affirmation of their potential benefits and practical advantages.
\end{abstract}

Keywords: antichresis; pactum antichreticum; Roman law; Act on Ownership and Other real Rights; security rights; settlement of claims.

\section{Zussamenfassung}

\section{ANTICHRESIS DE LEGE FERENDA}

Das kroatische Gesetz über das Eigentum und andere Sachenrechte verbietet durch Artikel 329 Paragraph 1 dem Grundschuldgläubiger den Besitz und das Nutzen der mit dieser Grundschuld belasteten Immobilie, was auch das Verbot des Fruchtziehungsrechts und anderer Nutzungsrechte an dieser Immobilie einschließt. Weiterhin schreibt Paragraph 2 desselben Artikels vor, dass jede Bestimmung, die im Vertrag anders als es im Paragraph 1 dieses Artikels vorgeschrieben ist, feststellen würde, nichtig ist. Mit dieser Bestimmung hat der kroatische Gesetzgeber das Pactum antichreticum verboten, während er die Antichresis als selbstständiger

* Ines Matić, Ph.D., Postdoctoral Student, Univeristy of Rijeka, Faculty of Law; imatic@pravri. hr.

** Anamari Petranović, Ph.D., Associate Professor, Univeristy of Rijeka, Faculty of Law; anamari. petranovic@pravri.hr. 
Vertrag überhaupt nicht anerkennt. Ziel dieses Beitrags ist, die potentiellen Vorteile der Regulierung des Instituts der Antichresis und/oder des Pactum antichreticum im kroatischen Recht de lege ferenda zu überprüfen. Deshalb stellt man im ersten Teil des Beitrags eine zusammenfassende historisch-rechtliche Analyse dieser Institute dar, die propädeutisch der komparativen Analyse dieser Institute in moderner Rechtsvergleichung dient. Die komparative Analyse wird im zweiten Teil des Beitrags durchgeführt, wonach man abschließend zu Erkenntnissen über potentielle Vorteile der Anwendung dieser Institute in Praxis kommt.

Schlüsselwörter: Antichresis; Pactum antichreticum; römisches Rech; Gesetz über das Eigentum und andere Sachenrechte; Sicherung der Forderung; Befriedigung der Forderung.

Riassunto

\section{L'ANTICRESI DE LEGE FERENDA}

La legge croata sulla proprietà e gli altri diritti reali all'art. 329, comma 1, pone il divieto in capo al creditore ipotecario di possedere o detenere un immobile che sia oggetto di ipoteca, incluso il divieto di godimento dei frutti anche civili dell'immobile, statuendo al capoverso dello stesso articolo la nullità di una previsione con la quale verrebbe definito il contrario. Con tale disposizione il legislatore croato vieta il pactum antichreticum, mentre l'anticresi quale fattispecie a sé stante non è affatto contemplata nella legislazione croata. Lo scopo di questo lavoro è valutare la potenziale opportunità della regolamentazione dell'istituto dell'anticresi e/o del pactum antichreticum nel diritto croato de lege ferenda. A tale fine, nella prima parte del lavoro si offre un'analisi storico-giuridica prodromica alla disamina comparata degli stessi istituti giuridici nel diritto comparato contemporaneo, che seguirà nella seconda parte del lavoro e mediante la quale si apprenderà se l'applicazione di tali istituti porti a dei vantaggi concreti della prassi.

Parole chiave: anticresi; pactum antichreticum; diritto romano; legge sulla proprietà e gli altri diritti reali; garanzia del debito; adempimento della prestazione. 